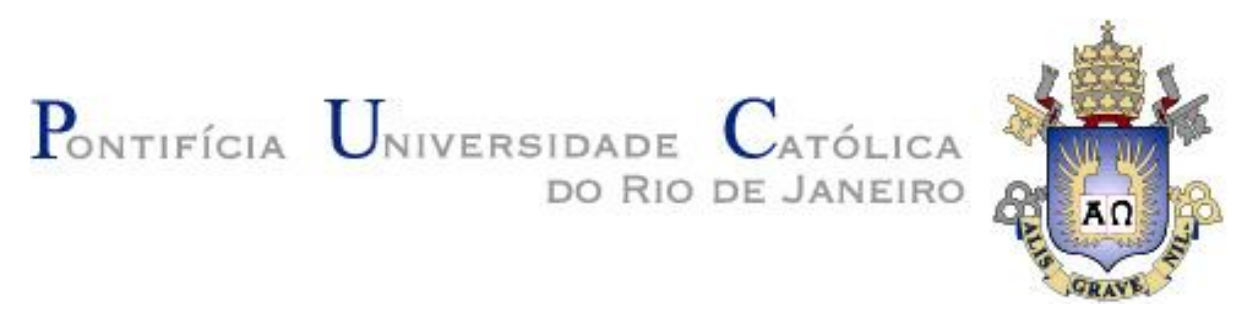

Ana Luísa França de Seixas Duarte

\title{
Avaliação Econômico-Financeira e Análise de Risco de Lançamentos Imobiliários no Contexto Brasileiro
}

Dissertação de Mestrado

Dissertação apresentada ao Programa de Pósgraduação em Administração de Empresas da PUCRio como requisito parcial para obtenção do título de Mestre em Administração de Empresas

Orientador: Prof. Leonardo Lima Gomes

Rio de Janeiro

Abril de 2016 


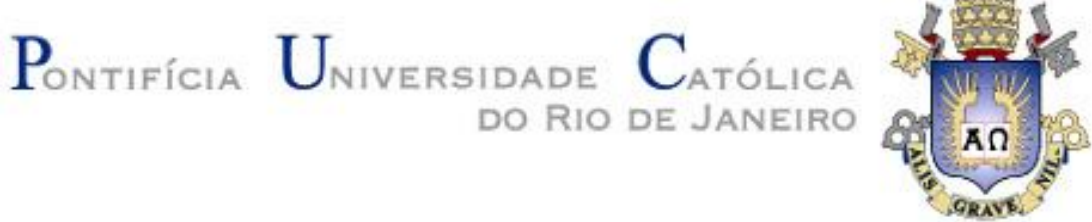

\author{
Ana Luisa Franca de Seixas Duarte
}

\title{
Avaliação Econômico-Financeira e Análise de Risco de Lançamentos Imobiliários no \\ Contexto Brasileiro
}

Dissertação apresentada como requisito parcial para obtenção do grau de Mestre pelo Programa de PósGraduação em Administração de Empresas do Departamento de Administração da PUC-Rio. Aprovada pela Comissão Examinadora abaixo assinada.

Prof. Leonardo Lima Gomes Orientador Departamento de Administração - PUC-Rio

Prof ${ }^{a}$. Graziela Xavier Fortunato Departamento de Administração - PUC-Rio

Prof. Carlos de Lamare Bastian Pinto Grupo IBMEC

Profa. Mônica Herz Vice-Decana de Pós-Graduação do CCS - PUC-Rio 
Todos os direitos reservados. É proibida a reprodução total ou parcial do trabalho sem autorização da universidade, da autora e do orientador.

\title{
Ana Luísa França de Seixas Duarte
}

\author{
Economista graduada na FGV-Rio
}

Avaliação econômico-financeira e análise de risco de lançamentos imobiliários no contexto brasileiro / Ana Luisa Franca de Seixas Duarte ; orientador: Leonardo Lima Gomes. - 2016.

57 f. : il. color. ; $30 \mathrm{~cm}$

Dissertação (mestrado)-Pontifícia Universidade Católica do Rio de Janeiro, Departamento de Administração, 2016. Inclui bibliografia

1. Administração - Teses. 2. Mercado imobiliário. 3. Risco. 4. Estudo de impacto. I. Gomes, Leonardo Lima. II. Pontifícia Universidade Católica do Rio de Janeiro. Departamento de Administração. III. Título. 
"A persistência é o menor caminho do êxito". (Charles Chaplin) 


\section{Agradecimentos}

A Deus, pela saúde e disposição para chegar ao fim de mais uma etapa.

Ao meu orientador, Prof. Leonardo Lima pela paciência e ensinamentos valiosos. A todos os professores do IAG da PUC-Rio pelos conhecimentos transmitidos.

Ao meu irmão, Gustavo França de Seixas Duarte, por servir de estímulo e inspiração diária.

Ao meu noivo, Bruno Pitta Pereira, pela paciência nas horas ausentes, pelo amor e constante incentivo.

A minha família, em especial minha mãe Vera Lucia França, que me ensinou a importância da educação.

À minha melhor amiga Antonia Maria Ventura, que me mostrou o verdadeiro sentido de dedicação e superação.

A todos os amigos que contribuíram direta e indiretamente para este trabalho. 


\section{Resumo}

Duarte, Ana Luísa França de Seixas; Gomes, Leonardo Lima. Avaliação Econômico-Financeira e Análise de Risco de Lançamentos Imobiliários no Contexto Brasileiro. Rio de Janeiro, 2016. 57p. Dissertação de Mestrado Departamento de Administração, Pontifícia Universidade Católica do Rio de Janeiro.

Após um período de estabilidade econômica e mudanças na regulação do setor imobiliário, as incorporadoras brasileiras lançaram inúmeros empreendimentos, contando que os índices econômicos financeiros fossem mantidos. Em geral, os projetos imobiliários lançados consideravam que a inflação permaneceria controlada, os juros continuariam em uma curva descendente, e a política de crédito ainda seria abundante. Contudo, a realidade deparada é oposta em diversos aspectos. Tal cenário contribuiu para a disparada das desistências dos contratos e para a estagnação do mercado imobiliário. Visto que neste mercado as incorporadoras precisam aguardar a entrega do empreendimento para receber a maior parte dos recebíveis, foram surpreendidas pela queda abrupta em seu fluxo de caixa. Neste trabalho, foi realizado uma análise de sensibilidade de um projeto imobiliário, considerando um cenário otimista, realista, pessimista e um de stress. O objetivo do trabalho é incluir a análise de risco de mercado e de crédito e seus impactos no estudo de viabilidade de um projeto imobiliário

\section{Palavras-chave}

Mercado imobiliário; risco; estudo de impacto. 


\section{Abstract}

Duarte, Ana Luísa França de Seixas; Gomes, Leonardo Lima (Advisor). Economic and Financial Evaluation and Real Estate Launches Risk Analysis in Brazilian Context. Rio de Janeiro, 2016. 57p. MSc. Dissertation - Departamento de Administração, Pontifícia Universidade Católica do Rio de Janeiro.

After a period of economic stability and changes in the regulation of real estate sector, brazilian developers launched countless projects, considering that the indexes would be kept. These firms believed that inflation would remain under control, interest rates would continue on a downward curve, and credit policy would still be abundant. However, nowadays, reality is the opposite in many aspects. This scenario contributed to an increase on contracts withdrawals and the stagnation of the housing market. Since, in this market, developers need to await until the conclusion of the project to receive most of their receivables, they were surprised by the sudden drop in theirs cash flows. In this work, a sensibility analysis of a real estate project was carried away, considering four scenarios: optimistic, realistic, pessimist and stress. The objective of this work is to include market and credit risk analysis and their impacts in a real estate viability study.

\section{Keywords}

Real Estate; Risk; Impact Study 


\section{Sumário}

$\begin{array}{lll}1 \text { Introdução } & 21\end{array}$

2 Referencial teórico 23

2.1. Análises do Mercado Imobiliário 23

2.2. Impactos dos Ciclos Econômicos no Mercado Imobiliário 24

$\begin{array}{ll}\text { 2.3. Value at Risk } & 25\end{array}$

3 Mercado Imobiliário no Brasil 26

3.1. FLUXO DO MERCADO IMOBILIÁRIO 30

4 Modelagem e Resultados 34

4.1. Premissas do modelo 34

4.2. Custo médio ponderado de capital 36

4.3. Cenário Base 38

4.4. Cenário Otimista 42

4.5. Cenário Pessimista 44

4.6. Cenário de Stress 46

4.7. Resumo da Análise de Sensibilidade 50

4.8. Gerenciamento de Risco 50

4.8.1. Análise de Risco do Cenário Base 50

5 Conclusão $\quad 54$

6 Referências bibliográficas $\quad 56$ 


\section{Lista de figuras}

Figura 1: Unidades Lançadas e Vendidas de 2003 a 2011 - Fonte: ABECIP-

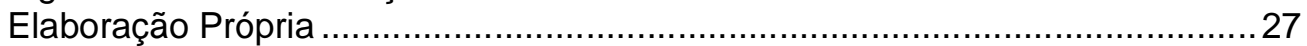

Figura 2: Variação de Financiamento Habitacional - Fonte: Bacen .....................28

Figura 3: Valor do $\mathrm{m}^{2}$ geral de venda na cidade do Rio de Janeiro - Fonte:

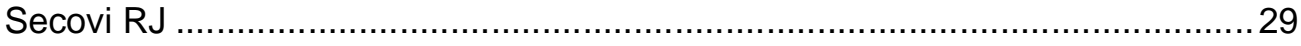

Figura 4: Concessões de Financiamentos - Fonte: ABECIP e BACEN .............30

Figura 5: Fluxo de Caixa Imobiliário - Fonte: ABRAINC …...............................33

Figura 6: Velocidade de Vendas no Cenário Base - Fonte: Elaboração Própria.41

Figura 7: Comparativo de Velocidade de Vendas entre os Cenários Otimista e

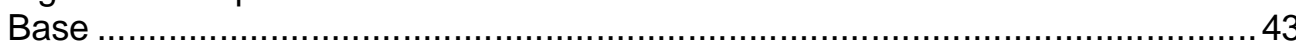

Figura 8: Comparativo da Velocidade de Vendas entre os Cenários Otimista, Base e Pessimista - Fonte: Elaboração Própria.............................................. 46

Figura 9: Comparativo da Velocidade de Vendas entre os Cenários Otimista, Base, Pessimista e Stress - Fonte: Elaboração Própria ...................................... 49

Figura 10: Distribuição Normal da Taxa de Desconto no Cenário Base ..............51

Figura 11: Distribuição Triangular para o Custo de Construção no Cenário

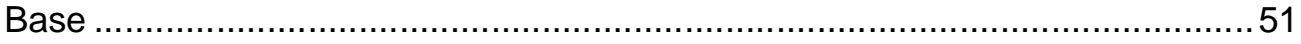

Figura 12: Distribuição Triangular para a Taxa de Distrato no Cenário Base .....52

Figura 13: Simulação de Risco da Margem VPL no Cenário Base.....................53 


\section{Lista de tabelas}

Tabela 1: Resumo do Empreendimento analisado - Fonte elaboração própria ..35

Tabela 2: Resumo dos Cenários da Análise de Sensibilidade ..........................36

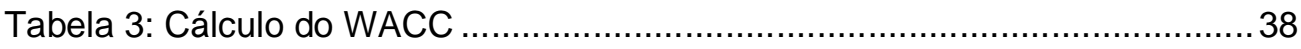

Tabela 4: Premissas do Cenário Otimista - Fonte: Elaboração Própria...............39

Tabela 5: Velocidade de Vendas Cenário Base .............................................. 40

Tabela 6: Velocidade de Vendas do Cenário Otimista - Fonte:

Elaboração Própria .................................................................................... 42

Tabela 7: Premissas do Cenário Pessimista - Fonte: Elaboração Própria.......... 44

Tabela 8: Velocidade de Vendas do Cenário Pessimista .................................. 45

Tabela 9: Premissas Cenário Stress ............................................................ 47

Tabela 10: Velocidade de Venda no Cenário de Stress ....................................48

Tabela 11: Resultado da Análise de Sensibilidade.........................................50 


\section{Glossário}

- ABECIP - Sigla de Associação Brasileira das Entidades de Crédito Imobiliário e Poupança.

- ADEMI - Sigla de Associação dos Dirigentes das Empresas do Mercado Imobiliário.

- Agente financeiro - Instituição pública ou privada que integra o Sistema Financeiro Nacional. Tem a função de coletar, intermediar e aplicar recursos financeiros próprios ou de terceiros na construção civil, com autorização do Banco Central.

- Alienação fiduciária - Ato de transferência de um bem móvel ou imóvel do devedor para o credor, em garantia do pagamento da dívida. $O$ devedor detém a posse do bem, para seu uso. Após a quitação da dívida, o comprador adquire a propriedade definitiva do bem

- Amortização - 1. Pagamento parcial e periódico de uma dívida. Pagamento de prestações ou parcelas. 2. Ato de amortizar.

- Avaliação - 1. Atividade que envolve a determinação técnica do valor qualitativo ou monetário de determinado bem, direito ou empreendimento. 2. Processo no qual um perito determina o valor de um bem que irá ser dado para hipoteca.

- Averbação - Anotação feita pelo Cartório de Registro de Imóveis de qualquer alteração que diga respeito ao proprietário (subjetiva) ou ao imóvel (objetiva).

- Back Office - Área de processamento e contabilidade que apóia e controla as operações realizadas pelas instituições financeiras

- Banco Central do Brasil (BC) - Autarquia federal, criada em 1964, que formula, executa e acompanha a política monetária, faz a emissão do dinheiro brasileiro, organiza e disciplina o Sistema Financeiro Nacional e fiscaliza as atividades do Sistema Financeiro da Habitação (SFH).

- Caixa Econômica Federal - Instituição financeira que atua em território nacional. Além de banco comercial, auxilia a execução da política de crédito para habitação do governo federal, com atribuições fiscalizadas pelo Banco Central do Brasil. A Caixa Econômica Federal também administra, desde 1990, o Fundo de Garantia por Tempo de Serviço (FGTS). 
- Carta de crédito - Documento concedido pelo banco (instituição financeira) ao pretendente de financiamento imobiliário com crédito já aprovado, ou seja, após análise dos documentos solicitados e a realização de pesquisa a respeito do comprador. A carta de crédito é válida por 30 dias, prorrogáveis pelo mesmo período, a critério do banco. Tão logo escolha o imóvel a ser adquirido, o comprador deverá assinar um compromisso de compra e venda com o vendedor. Esse contrato particular, juntamente com a documentação do imóvel e do vendedor, deve ser levado à instituição financeira para efetivação do processo de financiamento.

- Carteira Hipotecária $(\mathbf{C H})$ - Linha de crédito imobiliário utilizada por grande parte dos bancos privados. Os valores mínimo e máximo de financiamento são definidos pelas próprias instituições financeiras, com juros livres. As taxas mais usuais praticadas no mercado variam de $12,5 \%$ a $16 \%$ ao ano. Os candidatos a essa modalidade de financiamento não podem utilizar o saldo do FGTS como parte de pagamento, mas podem possuir outro imóvel (financiado ou não). $A$ garantia do banco é a hipoteca do imóvel financiado.

- Cash Flow - Demonstração de entradas e saídas de recursos do caixa de uma empresa, repartição pública ou governo.

- Caução - 1. Cautela que se toma para garantir o cumprimento de obrigações assumidas. 2. Depósito caução: depósito de valores para tornar efetivas as responsabilidades contratuais.

- Certidão - Documento expedido por determinado órgão, que garante a veracidade das informações nele contidas. As certidões podem ser solicitadas por qualquer pessoa.

- Certidão de Registro de Imóveis - Documento expedido por um Cartório de Registro de Imóveis, que garante ser correto determinado registro. A certidão pode ser requerida por qualquer pessoa, mediante pagamento de uma taxa.

- Cessionário - Pessoa a quem se transfere, por meio de cessão, direitos e/ou obrigações.

- Código de Defesa do Consumidor - Definido pela lei n. 8.078, de 11/09/1990. Visa proteger os direitos do consumidor. A lei estabelece como princípios fundamentais a nulidade de cláusulas abusivas, a 
facilitação da defesa, o prazo de reflexão e a responsabilidade do fornecedor por vício do produto ou serviço.

- Comprometimento de renda - Percentual de sua renda que o pretendente a financiamento imobiliário, por exemplo, pode utilizar (comprometer) mensalmente para o pagamento da prestação.

- Compromisso de compra e venda - Ver contrato de promessa de compra e venda.

- Comprovação de renda - Exigência para que o pretendente a financiamento imobiliário, por exemplo, comprove com documentos (holerite, carteira de trabalho, declaração de Imposto de Renda etc) que ganha o suficiente para arcar com as despesas em questão.

- Construtora - Empresa responsável pela construção de determinada obra.

- Contrato - Acordo, geralmente escrito, feito entre pessoas físicas e/ou jurídicas, em que cada lado se obriga a cumprir o que está determinado no documento. Um contrato entre partes adquire força de lei. Caso inclua cláusulas que contrariem leis superiores, serão consideradas nulas (sem validade).

- Contrato de compra e venda - Contrato em que são pactuadas as condições de compra e venda de um imóvel, por exemplo. Documento pelo qual o vendedor obriga-se a transferir o domínio de certo bem ao comprador, no preço, prazo e demais condições ajustadas.

- Contrato de promessa de compra e venda - Contrato pelo qual o proprietário de um bem assume o compromisso de vendê-lo ao outro contratante, que, por sua vez, se compromete a comprá-lo no prazo e preço estipulados.

- Correção monetária - Mecanismo para atualizar o valor da moeda e seu poder de compra, com base em índice de inflação apurado no período. A correção monetária visa compensar os efeitos da inflação.

- Crédito habitacional - Empréstimo concedido por instituições financeiras para comprar, construir, reformar ou financiar um imóvel.

- Crédito Imobiliário - Crédito especializado, dirigido ao financiamento habitacional. 


\section{Disponível em dois sistemas:}

- SFH - Sistema Financeiro da Habitação: para operações de cunho social, voltado especialmente para classes sociais mais pobres;

- SFI - Sistema de Financiamento Imobiliário: para operações de cunho comercial, subordinado às taxas de mercado, podendo constituir garantias sob a forma de hipoteca ou alienação fiduciária do imóvel financiado.

- Credor - Aquele que concede a uma pessoa ou empresa um crédito (empréstimo).

- Cronograma financeiro - Representação gráfica dos valores financeiros previstos para a execução de determinada obra.

- Cronograma físico - Representação gráfica do tempo previsto para a execução de determinada obra.

- Cronograma físico-financeiro - Representação gráfica que indica, simultaneamente, o tempo e os valores financeiros previstos para a execução de determinada obra.

- Depreciação - Perda do valor anterior de mercado de um imóvel ou terreno. A depreciação pode ocorrer em função de vários fatores, como mau uso e falta de conservação do bem, degradação socioeconômica e deficiência de investimentos públicos na região, falta de atrativos para novos projetos imobiliários e demais investimentos privados, momento desfavorável da atividade econômica do país, entre outros.

- Distrato - Verificar em Rescisão

- Entrega - Ato de se entregar aos compradores das unidades de determinado empreendimento as suas respectivas áreas privativas e comuns. Para formalizar a entrega, nesta fase geralmente também se realiza a assembleia de instalação de condomínio.

- Escritura definitiva - Ato jurídico, lavrado em Cartório, em que o vendedor transmite ao comprador a posse e domínio de imóvel, quando integralizado o preço. É necessário que a escritura definitiva seja registrada junto ao Serviço de Registro de Imóveis da circunscrição do imóvel para que a propriedade seja regularmente transferida.

- Habite-se - Auto de conclusão da obra, lavrado pelo poder público municipal, que atesta a habitabilidade da mesma. O imóvel só pode ser ocupado depois da concessão do Habite-se. A emissão do documento implica em vistorias no local, quando se verifica se a obra foi executada 
de acordo com o projeto aprovado, e também se atende a vários requisitos legais (parecer do Corpo de Bombeiros, das companhias de energia elétrica, água e gás, entre outras).

- Hipoteca - 1. Sujeição de bens imóveis e outros ao pagamento de determinada dívida, sem que se transfira ao credor a posse do bem em questão. Em caso de inadimplência, o credor de hipoteca pode ter preferência no direito de promover a venda judicial do bem hipotecado.

2. Dívida resultante dessa sujeição.

- IGP-M - Sigla de Índice Geral dos Preços - Mercado, calculado e divulgado pela Fundação Getúlio Vargas. Nos contratos de compra e venda de imóveis, por exemplo, o IGP-M é um índice que pode ser utilizado para atualização monetária, principalmente após a conclusão das obras.

- Imóvel alienado - Ver hipoteca e alienação fiduciária.

- Imóvel na planta - Designação usual para imóvel comercializado na fase de lançamento, ou seja, antes do início de sua construção.

- Inadimplemento - O mesmo que inadimplência.

- Inadimplência - Descumprimento de um contrato ou de qualquer uma de suas condições. É chamado de inadimplente o devedor que não cumpre as obrigações contratuais da forma pactuada.

- INCC - Sigla de Índice Nacional de Custo da Construção Civil, calculado e divulgado pela Fundação Getúlio Vargas.

- Incorporação imobiliária - 1. Ato ou efeito de incorporar ou empreender um projeto imobiliário. 2. Conjunto de atividades através das quais é possível uma empresa ou pessoa física construir uma edificação, promovendo a alienação total ou parcial das unidades autônomas que a compõem. 3. Processo que permite a comercialização legal de uma edificação que ainda está na planta ou em fase de construção.

- Incorporador(a) - Pessoa física ou jurídica que promove a incorporação imobiliária em sistema de condomínios, podendo comercializar as unidades autônomas antes de estarem prontas - comprometendo-se, por contrato, a entregar os imóveis dentro das condições e prazos determinados.

- Índice setorial - Índice relativo ou pertencente a um determinado setor de atividade econômica. No âmbito da construção, pode-se citar o INCC 
(Índice Nacional de Custo da Construção Civil), da Fundação Getúlio Vargas, como exemplo de índice setorial.

- Início das obras (fase de) - Estágio da obra que começa com a instalação do canteiro de obras no terreno. Nos projetos em que estão previstos subsolos (garagens subterrâneas), inicia-se os trabalhos de escavação e fundações. Esta fase pode se estender por um período de 4 a 6 meses, porque exige trabalho meticuloso, que forma os alicerces da construção.

- IPTU - Sigla de Imposto Predial Territorial Urbano. Tributo municipal cujo fato gerador é a propriedade de imóvel territorial urbano. A base de cálculo para a cobrança do IPTU é o valor venal do imóvel - valor estimado de venda do bem, que leva em consideração metragens, localização, destinação e tipo do imóvel.

- ITBI - Sigla de Imposto de Transmissão de Bens Imóveis. Também denominado Imposto de Transmissão Intervivos em alguns municípios. Tributo cujo fato gerador é a transação imobiliária, cobrado pela prefeitura sempre que há transmissão de propriedade de bens imóveis. O recolhimento dessa taxa, que varia de acordo com a legislação estadual, é de responsabilidade do comprador. Em São Paulo, por exemplo, a taxa é de $2 \%$ sobre o valor do imóvel.

- Lançamento imobiliário - Divulgação ao público, após o registro de incorporação, de determinado empreendimento imobiliário - através de eventos, ações promocionais, anúncios na mídia, e etc. É no lançamento que se disponibiliza as unidades para venda, sendo que no local onde o projeto será construído é montado um estande de vendas.

- Laudêmio - Imposto pago a cada transação de compra e venda por qualquer imóvel que esteja em área da União, como aqueles que se localizam na orla marítima. Quando alguém decide vender um imóvel que esteja em área da União, precisa pedir uma certidão de ocupação ou aforamento (conforme a classificação do terreno) à gerencia regional da Secretaria do Patrimônio da União, órgão ligado ao Ministério do Planejamento. Sem essa certidão, os cartórios de notas e registro de imóveis estão impedidos, por lei, de lavrar e registrar a escritura.

- Lei de Incorporações - Lei federal $n^{\circ} 4.591$, de 1964, que dispõe sobre condomínios em edificações e incorporações imobiliárias. 
- Liquidação antecipada - Pagamento total de uma dívida antes do prazo fixado em contrato.

- Memorial de incorporação - Documento jurídico que detalha o objeto da incorporação, com definição das áreas de uso privativo e comum, especificação dos acabamentos da edificação - conforme modelo da Associação Brasileira de Normas Técnicas (ABNT) etc. Por exigência legal, antes de comercializar as unidades autônomas, o incorporador deve arquivar o documento no Cartório de Registro de Imóveis competente.

- Memorial descritivo - 1. Documento que especifica os materiais e equipamentos que serão aplicados na construção. O incorporador deve esse documento arquivado no Registro de Imóveis antes do início da venda das unidades. 2. Anexo dos contratos de compra e venda de imóvel na planta ou em construção, o memorial descreve o que está sendo comprado, seguindo as normas da ABNT (Associação Brasileira de Normas Técnicas). No documento, ainda devem constar a metragem da área útil e de uso comum, a localização das vagas de garagem e a especificação da lista de acabamentos - com indicação de marca, fabricante e/ou categoria.

- Mutuário - Aquele que recebe um bem fungível em um contrato de mútuo.

- Mútuo - Contrato de reciprocidade pelo qual o proprietário (mutuante) transfere um bem fungível a outro (mutuário), que deve lhe restituir o que foi emprestado. Os contratos de financiamento imobiliário são um exemplo de mútuo.

- Obra - Realização de trabalho em terreno ou imóvel, desde seu início até sua conclusão, cujo resultado implique na alteração de seu estado físico anterior.

- Permuta - Troca. Transferência mútua e simultânea de bens, como imóveis, entre seus respectivos proprietários. Diz-se 'permuta com torna' para a troca em transação imobiliária com parte de pagamento em dinheiro; e 'permuta sem torna' para a transação que não envolva dinheiro.

- Prazo de financiamento - Espaço de tempo convencionado para a realização de um financiamento. 
- Pré-lançamento - Fase que precede o lançamento oficial de um projeto imobiliário, sem presença maciça na mídia, divulgado apenas a um público restrito. No pré lançamento, a comercialização geralmente ainda não foi iniciada, mas pode-se reservar unidades para compra futura.

- Quitação - 1. Ato de quitar, pagar integralmente uma dívida. 2. Prova de pagamento de dívida, mediante recibos e/ou outros documentos. 3. Ato escrito no qual o credor declara ter recebido do devedor 0 pagamento da dívida, liberando-o dessa obrigação.

- Reajuste - Aplicação de juro e correção monetária ao saldo devedor e/ou ao encargo mensal, de acordo com o índice estipulado em contrato.

- Registro de Imóveis - 1. Inscrição do documento relativo à propriedade de um imóvel no registro competente, para que o direito de propriedade tenha validade legal. O Registro de Imóveis é o documento em que se realizam todas as mudanças, alterações e extinções dos direitos referentes ao imóvel, com caráter de autenticidade. Em outras palavras, o documento, além de estabelecer o direito de propriedade, arquiva 0 histórico completo do imóvel. 2. Cartório especial onde são praticados todos os atos relativos à constituição, declaração, transferência ou extinção de direitos reais sobre os imóveis.

- Rescisão - Rompimento ou anulação de um contrato.

- Saldo devedor - Valor restante para a quitação total de um bem móvel ou imóvel. Nos financiamentos imobiliários, o saldo devedor é reajustado mensalmente de acordo com a taxa de juros e o índice estipulados em contrato

- Saldo residual - É o valor que resta (a mais ou a menos) de uma dívida, quando vencido o prazo contratado.

- Securitização - Conversão de empréstimos bancários e outros ativos em títulos (em inglês, securities) para vendê-los a investidores. A instituição que fez o empréstimo vende-o a uma empresa securitizadora. Com lastro nesse crédito, a securitizadora emite "certificados de recebíveis imobiliários" que podem ser comercializados à investidores. A securitização do crédito imobiliário pode ser feita quando a instituição financeira o concedeu de acordo com a lei n.o 9.514, que criou o Sistema de Financiamento Imobiliário (SFI) 
- SFH - Sigla de Sistema Financeiro da Habitação. Criado pela lei federal no 4.320 de 04/08/1964, o SFH tem como objetivo a captação de recursos a juros baixos (oriundos dos depósitos em caderneta de poupança e do FGTS) para repasse à área habitacional, na forma de financiamento para a produção de imóveis e a compradores da casa própria. Pelas regras do SFH, o imóvel tem que ser para uso próprio do mutuário, sendo permitida a utilização do FGTS para abatimento da dívida; o valor máximo de financiamento é de $R \$ 150$ mil; o candidato à compra não pode ter outro imóvel financiado e a taxa de juros é de no máximo 12\% ao ano. A garantia do banco é a hipoteca do imóvel.

- SFI - Sigla de Sistema de Financiamento Imobiliário. Criado pela lei federal no 9.514 de 20/11/1997 como uma alternativa ao Sistema Financeiro de Habitação e à Carteira Hipotecária. Os recursos do SFI provêm da captação dos próprios bancos e da securitização. Pode ser usado no financiamento de imóveis usados, na planta e em construção, não havendo limite para faixa de crédito. É permitida a utilização do FGTS na quitação total do saldo devedor e a taxa de juros é de no máximo $12 \%$ ao ano. A garantia do banco é a hipoteca ou a alienação fiduciária do imóvel.

- Tabela Price - Tabela para cálculo de prestações de um financiamento, também chamada de Sistema Francês de Amortização. Como em outros sistemas, cada prestação é resultante de duas partes: uma de amortização da dívida principal e outra de juros. O método de cálculo da Tabela Price consiste em manter prestações constantes, sendo que, ao longo do prazo de financiamento, a parte da amortização aumenta, enquanto a participação dos juros decresce.

- Taxa efetiva - Qualificada como efetiva quando o período de formação e o período de incorporação de juros ao capital coincide com aquele a que a taxa está referenciada.

- Taxa nominal - Qualificada com nominal quando o período de formação e o período de incorporação de juros ao capital não coincide com aquele a que a taxa está referenciada.

- TR - Sigla de Taxa Referencial, divulgada mensalmente pelo Banco Central, com base na remuneração média das aplicações bancárias. $A$ TR é utilizada como indexador da caderneta de poupança, débitos fiscais, contratos privados, etc. Trata-se também de um índice aplicado 
com frequência nos reajustes de prestações dos contratos de financiamento imobiliário.

- Transmissão - Cada uma das transferências de propriedade, direitos ou obrigações entre pessoas ou por herança.

- Unidade autônoma - Parte de uma edificação (residencial ou não) vinculada a uma fração ideal de terreno, constituída de dependências e instalações de uso privativo e de parcela de dependências e instalações de uso comum. 


\section{1 \\ Introdução}

O setor imobiliário possui elevada importância para o desenvolvimento econômico do Brasil. A atividade é grande geradora de emprego, contratando mão de obra dos mais diversos níveis de instrução e qualificação. Outro aspecto é a grande relevância do setor para o nível de investimento da economia e, consequentemente, para a determinação do nível de renda. Durante décadas, a economia do país apresentou altas taxas de inflação, falta de regulação no setor, juros altos, dentre outros fatores. Tais indicadores contribuíram para um baixo desempenho do setor.

Porém, a partir dos anos 2000, o mercado imobiliário apresentou taxas de crescimento robustas, atingindo uma expansão $51,1 \%$ no ano de 2010 . O controle da inflação, a reforma regulatória no setor, a redução gradual da taxa SELIC, os programas governamentais estimulando a concessão do crédito imobiliário, dentre outros, contribuíram para que a população brasileira passasse a se interessar cada vez mais pela aquisição de um imóvel. As incorporadoras, por sua vez, aumentaram os lançamentos de empreendimentos imobiliários, considerando que as condições econômicas favoráveis perdurassem a longo prazo. Contudo, o que foi constatado é o oposto em diversos aspectos: o retorno da alta inflação, curva de juros ascendente, perda de poder aquisitivo da população, escassez de crédito e, consequentemente, excesso de oferta de unidades imobiliárias no mercado.

Visto que o ciclo imobiliário é longo e dependente dos índices econômicofinanceiros, é notório que as empresas não se prepararam para a realidade atual. A falta desta previsão impactou negativamente nos resultados das incorporadoras, arriscando inclusive, a sobrevivência das mesmas. Portanto, o objetivo deste trabalho é incluir nos estudos de viabilidade de um projeto imobiliário uma análise do risco de mercado, chegando-se à seguinte questão de pesquisa: Como modelar uma análise de risco considerando as especificidades do setor imobiliário brasileiro, analisando possíveis impactos na tomada de decisão das empresas? 
Atualmente os resultados estão cada vez mais pessimistas para a construção civil e para a economia brasileira como um todo, evidenciando a importância de se ter feito análises de risco.

Há dois anos, por exemplo, as previsões não apontavam para tamanha retração econômica. Contudo, mesmo que improvável, a mesma é uma realidade no Brasil. As empresas do ramo imobiliário devem analisar a possibilidade de mudanças drásticas de rumo da economia. Avaliar a inclusão de cenários menos favoráveis contribuirá para a sustentabilidade das empresas do ramo, tão importante para o crescimento econômico do país.

Essa dissertação está organizada da seguinte forma: o capítulo 2 apresentará artigos acadêmicos que abordam os indicadores adotados em uma análise de viabilidade imobiliária, o comportamento do setor, e as metodologias que devem ser utilizadas a fim de avaliar o risco do negócio. No capítulo 3 serão apresentados a evolução do mercado imobiliário no Brasil e como são formados os fluxos de caixa de empreendimentos do setor. No capítulo 4 será apresentado um exemplo de avaliação e análise de risco de um empreendimento residencial. No capítulo 5 serão apresentadas as conclusões, limitações do estudo e sugestões

para trabalhos futuros. 


\section{2 \\ Referencial teórico}

Neste capítulo serão discutidos aspectos teóricos e estudos relacionados ao tema de investigação. Esta seção está dividida em três partes e abordam, respectivamente, análises do setor de real estate, os comportamentos do ciclo imobiliário e a utilização do Value At Risk no estudo a fim de análisar os riscos do mercado.

\section{1. \\ Análises do Mercado Imobiliário}

Ebrahim e Hussain (2010) defendem que o mercado de capitais deve ser mais utilizado no setor imobiliário. O estudo mostra que tal mercado deve atuar mais ativamente nos projetos imobiliários através de fundos imobiliários, permitindo que os mesmos invistam mais neste setor. Segundo os mesmos, o mercado de capitais oferece mais opções ao investidor do que os bancos. Isto ocorre em função da intensa regulamentação sobre os bancos, dificultando a liquidez dos investimentos.

Koetter e Poghosyan (2010) demonstram que um aumento excessivo nos preços dos imóveis pode comprometer a solidez do mercado financeiro. $O$ artigo reúne dados do setor imobiliário e de bancos da Alemanha e conclui que os desvios nos preços dos imóveis promovem um aumento de oferta de crédito para mutuários arriscados a uma taxa de juros relativamente baixa. Os autores defendem maior padronização na precificação dos imóveis a fim de mitigar eventuais desequilíbrios no sistema bancário. 


\section{2. \\ Impactos dos Ciclos Econômicos no Mercado Imobiliário}

Uma avaliação tradicional de um projeto considera um fluxo de caixa estável onde a taxa de valorização do imóvel é sempre positiva. Em um ciclo longo como o imobiliário, é importante considerar que ciclos econômicos existem e os mesmo podem afetar a viabilidade de um projeto.

Witten (1987) mostra que os fatores da economia são cíclicos e que os mesmos afetam uma avaliação de fluxo de caixa. O autor constatou que cada cidade possui o seu próprio ciclo, com características únicas e dependentes da dinâmica interna de cada mercado. Atesta também que a oferta possui um comportamento mais cíclico que a demanda, considerando que ela é determinada pela disponibilidade do financiamento.

Wheaton (1987) a partir de uma amostra de dados de dez cidades americanas estimou que os ciclos possuíssem uma extensão de 10 a 12 anos. 0 referido autor desenvolveu um modelo de análise no qual a oferta era um resultado da amostra à demanda com um período de defasagem, mas a oferta responde mais prontamente aos fatores econômicos, tais como, indicadores de crescimento e taxas de juros que a demanda local.

Conforme Roulac (1982), análises de investimentos e técnicas de valuation devem ser compatíveis com a dinâmica de mercado.

Frew e Jud (1988) e Grebler and Burns (1982) deram especial atenção ao impacto da inflação nos retornos dos projetos imobiliários.

De acordo com Fortunato (2008), os preços dos imóveis além de serem afetados pela demanda do mercado local, são afetados também por fatores macroeconômicos e podem apresentar volatilidade significativa. Um aumento na taxa de juros eleva os ganhos na aplicação financeira de renda fixa, acarretando uma queda nos investimentos imobiliários e afetando negativamente os preços dos imóveis. Tal volatilidade contribui para o incremento das desistências por parte dos promitentes compradores. A queda nos investimentos imobiliários obriga uma redução de preço, a fim de garantir os fluxos de caixa necessários à construção de um imóvel.

Com o objetivo de reduzir a falta de padronização dos preços dos imóveis, Narula, Wellington e Lewis (2011) propõem avaliar o preço de um imóvel residencial considerando como variáveis dependentes como a idade do 
ativo, a metragem, quantidade de quartos e demais fatores através de uma regressão paramétrica.

\section{3.}

Value at Risk

O cálculo do Valor em Risco (ou VAR) é um método de se obter o valor esperado da máxima perda (ou pior perda) dentro de um horizonte de tempo com um intervalo de confiança. Portanto, visto que o ciclo imobiliário é suscetível aos indicadores econômicos, deve-se atribuir uma probabilidade de mudança de cenário ao longo da construção do projeto.

Bawa (1978) indtroduziu conceito de Var, uma medida de gerenciamento de risco, contudo o mesmo oi pouco utilizado até o início da década de 90. Kuruc and Lee (1998) discutem as informações que o Var disponibiliza para a estratégia das empresas. 


\section{3 Mercado Imobiliário no Brasil}

Até meados da década de 90, o mercado imobiliário brasileiro apresentou uma estagnação, mesmo com a necessidade de redução do déficit habitacional no país.

O FGTS e o SBPE foram criados no final da década de 60 a fim de disseminar o crédito imobiliário para a população brasileira, contudo a pressão inflacionária iniciada em 1970, com o auge na década de 80 , freou tais operações. As correções monetárias utilizadas nos contratos de financiamento eram atreladas a inflação, e os salários não conseguiram absorver este incremento gerando uma elevação considerável na taxa de inadimplência.

Com o Plano Real, estabilização da economia e controle da inflação, o processo de financiamento imobiliário iniciou sua retomada. A criação da Alienação Fiduciária em 1997 incentivou a concessão do financiamento imobiliário por parte dos agentes credores.

De acordo com o relatório de inflação emitido pelo Banco Central em setembro de 2010 (pag. 48), "o volume das operações de crédito habitacional às famílias registrou expansão de 327\% de julho de 2005 a julho de 2010, atingindo $R \$ 116$ bilhões." O mesmo relatório também cita o acréscimo dos empréstimos para os incorporadores ( pag. 49): "As carteiras dos segmentos de incorporação de empreendimentos imobiliários e de construção de edifícios, representadas por operações em diversas modalidades de crédito, totalizaram $R \$ 34,3$ bilhões em julho de 2010, aumentando 531\% em relação ao período correspondente de 2005, com ênfase na expansão de $808 \%$ observada no segmento de incorporação, cuja carteira totalizou $R \$ 18,7$ bilhões."

A implementação do programa Minha Casa, Minha Vida (MCMV), que visava a produção de novas unidades habitacionais destinadas a famílias com 
renda de até dez salários mínimos, com aporte de recursos do orçamento da União e do FGTS e abertura de capital das incorporadoras na lbovespa também contribuíram para este cenário de aquecimento.

Foi detectado, portanto, um incremento de lançamentos imobiliários e concessões de financiamento habitacionais, conforme gráficos abaixo:

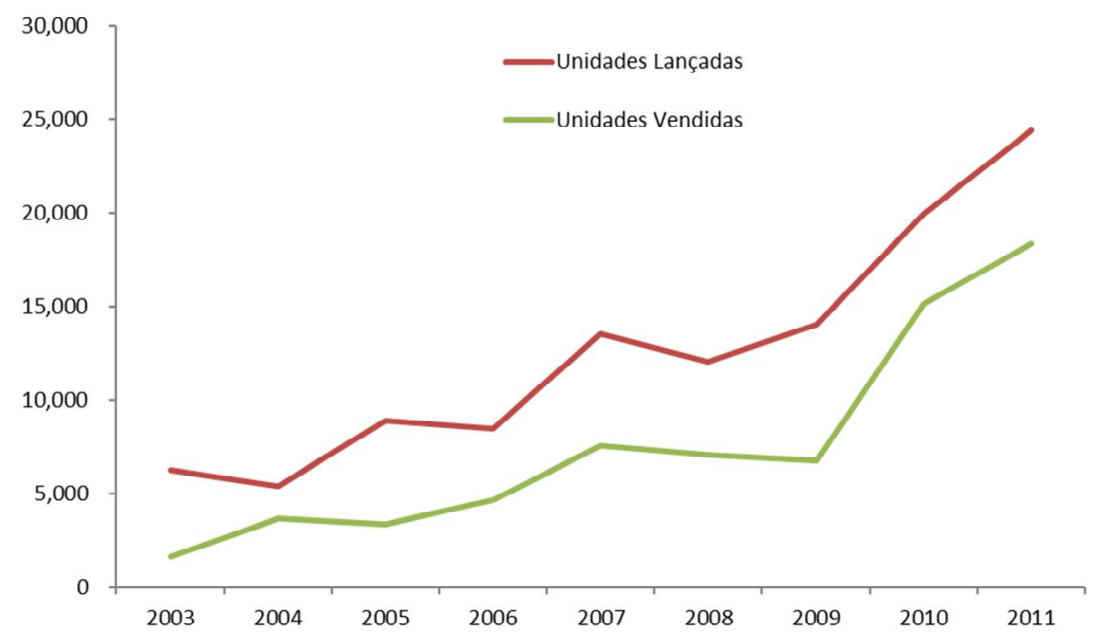

Figura 1: Unidades Lançadas e Vendidas de 2003 a 2011 - Fonte: ABECIP- Elaboração Própria

A concessão de financiamento imobiliário seguiu a mesma tendência dos lançamentos. Pode-se constatar esta curva ascendente através da figura 2. 


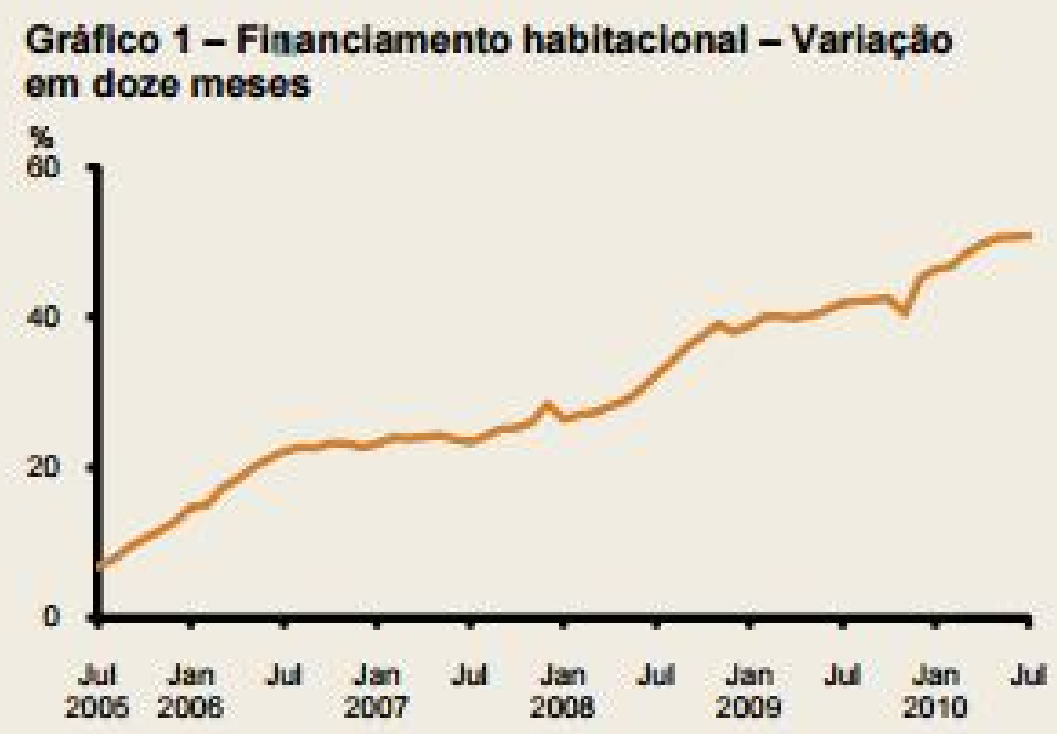

Figura 2: Variação de Financiamento Habitacional - Fonte: Bacen

O otimismo do setor impossibilitou que fossem considerados cenários mais pessimistas nas entregas dos empreendimentos. No estudo de viabilidade do projeto imobiliário, eram desconsideradas as possibilidades de um aumento na inflação, na perda do poder aquisitivo dos compradores e na retração do crédito.

Contudo, o que foi desconsiderado nas viabilidades dos projetos imobiliários está se tornando realidade. O aumento da inflação, a elevação dos juros e a desconfiança dos consumidores e das instituições financeiras estão impactando diretamente nos empreendimentos que estão sendo entregues desde 2015, agravando - se para o ano de 2016.

Os distratos, que são as desistências dos contratos por parte dos promitentes compradores vêm disparando, e os incorporadores precisarão enfrentar a realidade não prevista.

Apesar do caráter irrevogável e irretratável da Promessa de Compra e Venda de uma unidade autônoma, os promitentes compradores e as incorporadoras podem chegar a um acordo para rescisão deste contrato. Caso não haja acordo bilateral, os promitentes compradores conseguem na Justiça, a devolução de $80 \%$ do valor pago corrigidos. 
Com a deterioração macroeconômica, verifica-se uma diminuição do ritmo da valorização do $\mathrm{m}^{2}$ no Rio de Janeiro. Conforme figura abaixo se constata uma curva descendente nos valores dos imóveis no Rio de Janeiro.

Valor do $\mathrm{m}^{2}$ geral de venda na cidade do Rio de Janeiro - jan/12 x dez/15

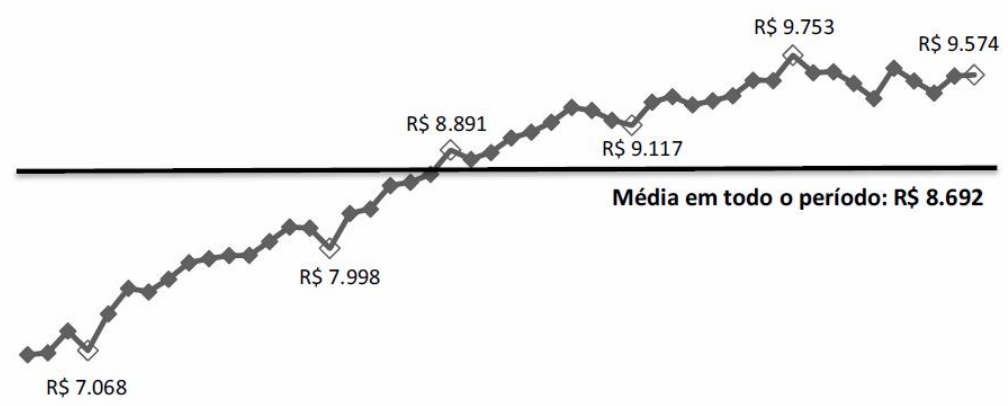

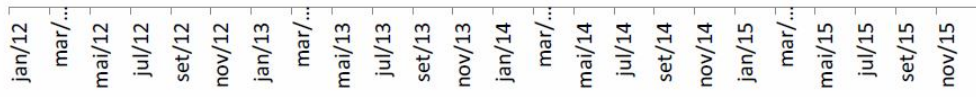

Fonte: Secovi Rio

Figura 3: Valor do $\mathrm{m}^{2}$ geral de venda na cidade do Rio de Janeiro - Fonte: Secovi RJ

Além disso, a contratação do financiamento bancário está menor que nos anos anteriores. Esta retração pode ser atribuída à perda de funding dos bancos, ao aumento do desemprego e ao encarecimento da modalidade de crédito. 


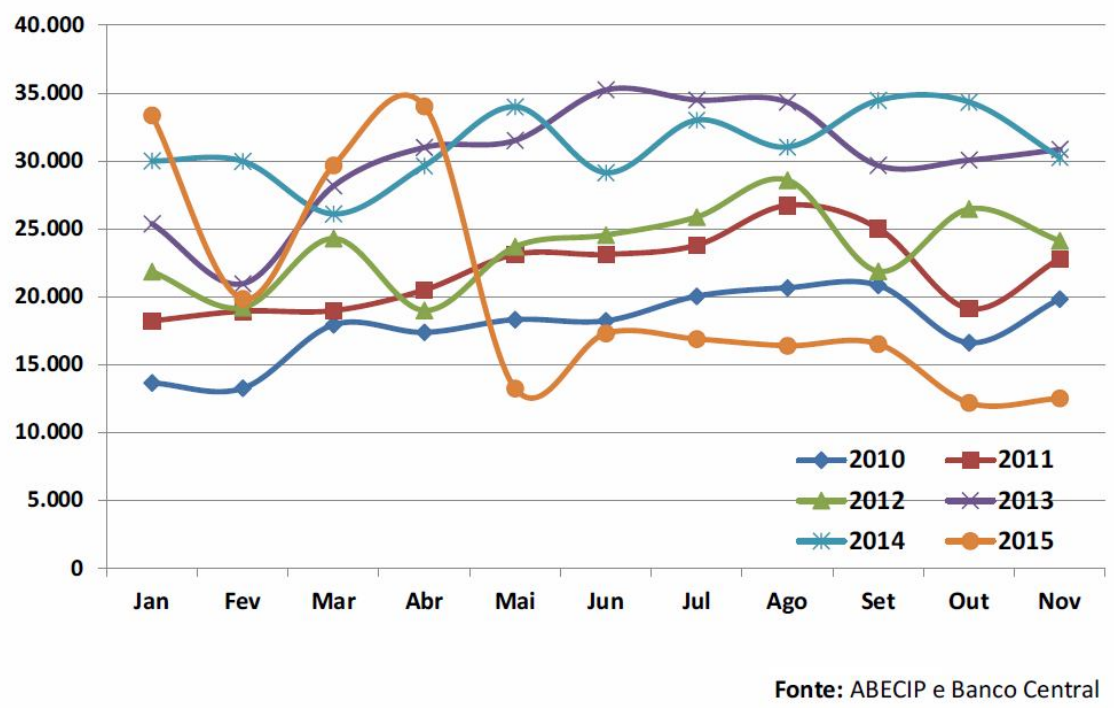

Figura 4: Concessões de Financiamentos - Fonte: ABECIP e BACEN

\section{1. FLUXO DO MERCADO IMOBILIÁRIO}

O fluxo de um projeto imobiliário é extremamente alavancado. Isto ocorre porque antes do lançamento, o incorporador já teve que realizar análises do terreno, viabilidade do projeto, legalização do empreendimento junto aos órgãos competentes, marketing e demais despesas.

Caso não ocorra permuta na negociação com os donos do terreno, já ocorrerá desembolso considerável em seu caixa, pois o mesmo não está atrelado ao sucesso/fracasso do empreendimento. A permuta nada mais é que o pagamento do terreno em unidades que serão construídas no local. A permuta é favorável para o incorporador, visto que diminui sua exposição de caixa.

Portanto, antes mesmo de iniciar a comercialização das unidades imobiliárias, o acionista já deve possuir capital suficiente para arcar com todos os custos inerentes ao projeto.

Podemos citar alguns custos incorridos antes da realização do lançamento imobiliário.

- Estudo do mercado em que o terreno se localiza

- Aquisição do terreno

- Elaboração do Produto 
- Legalização do terreno junto à Prefeitura e demais órgãos competentes

- Marketing para a divulgação do Produto

- Construção do Stand de Vendas

Além das despesas que ocorrem antes do lançamento, existem os custos que ocorrem posteriormente à comercialização. São os custos de obra, gerenciamento do projeto, impostos, licenciamentos, entre outros.

A receita deste projeto inicia-se apenas a partir do lançamento das unidades ao mercado. $E$ mesmo assim, o proponente comprador não efetua 0 pagamento integral sua unidade. A tabela de vendas, normalmente, considera $o$ pagamento de $30 \%$ a $40 \%$ do valor do imóvel durante a fase de obras e o restante apenas no repasse, que é o momento em que o cliente busca financiamento imobiliário junto à instituição bancária de sua preferência.

O repasse imobiliário tende a iniciar após a expedição do habite-se do empreendimento, e depende da capacidade de crédito do promitente comprador e na disponibilidade da instituição financeira em realizar empréstimos a juros relativamente baixos e prazos extremamente longo, comparado às demais modalidades. A velocidade de vendas, portanto, é algo crucial para o empreendimento. Quanto mais rápido for, menos equity será demandado.

Diante do exposto, como o incorporador conseguiria financiar o seu projeto visto que as suas despesas e receitas são descasadas? Além do capital próprio, existe uma linha de crédito para esta finalidade chamada "Plano Empresário".

De acordo com o Relatório de Inflação do Bacen de 2010 "O Plano Empresário é uma linha de financiamento imobiliário direcionada à construção de empreendimentos residenciais ou comerciais com recursos do Sistema Brasileiro de Poupança e Empréstimo (SBPE), mediante garantia de hipoteca e adoção do instituto do patrimônio de afetação (PA) ou de Sociedade de Propósito Específico (SPE). O PA, regulamentado pela Lei no 10.931, de 2 de agosto de 2004, tem a finalidade básica de segregar o patrimônio do empreendimento imobiliário das demais empresas componentes do grupo econômico. A SPE deve ter como objetivo a gestão de um único empreendimento, contando com contabilidade própria, embora seja vinculada à empresa principal do grupo."

A SPE - Sociedade de Propósito Especifico, tem o objetivo de garantir que os recursos do financiamento sejam utilizados exclusivamente pelo empreendimento em questão, Esta ferramenta foi criada após o episodio da 
Encol, onde verificou-se que um empreendimento era sustentado a partir de recursos provenientes do lançamento de outro.

O Patrimônio de Afetação tem a mesma finalidade que a SPE. O objetivo é assegurar direitos aos adquirentes de unidades autônomas de edifício em construção no caso de falência ou insolvência civil do incorporador, aperfeiçoar as relações jurídicas e econômicas entre esses adquirentes, o incorporador e o agente financiador da obra. Também foi criado após o episódio da Encol.

O funding proveniente desta modalidade de financiamento é oriundo do SBPE - Sistema Brasileiro de Poupança e Empréstimo, que utiliza recursos depositados na Poupança para a concessão de créditos imobiliários.

Além da instauração do Patrimônio de Afetação de da Sociedade de Patrimônio Especifico, os bancos exigem outras garantias para a liberação dos recursos para a construção de um empreendimento.

- Garantias financeiras que podem ser através de depósitos em dinheiro em contas bloqueadas e ou hipotecas das unidades em construção

- Contratação de Seguros Específicos (Seguro Garantia ao Construtor e Risco de Engenharia)

- Determinação de um gatilho de vendas para o inicio das liberações. Normalmente tal gatilho é de $30 \%$.

As liberações do Plano Empresário são mensais, conforme o andamento de obra atestado no mês anterior. Novamente, o incorporador precisa desembolsar o recurso primeiro para depois ter a parcela liberada pelo banco. Portanto, as liberações dependem tanto do andamento de obra quanto da expectativa de vendas acordada com o banco financiador. Mesmo com 0 andamento de obra conforme cronograma, caso as vendas frustrem o que foi acordado com o banco, não haverá liberação da parcela de financiamento e a obra deverá será custeada pelo equity. O "Plano Empresário" não financia o terreno. A instituição financeira concede recursos equivalentes a até $80 \%$ do Custo de Obra Total, que abrange o custo de obra para a construção das unidades imobiliárias, despesas de incorporação, e eventuais custos com o terreno após a aquisição do mesmo.

A fim de amenizar o descasamento entre receitas e despesas, na DRE é utilizado o método conhecido como POC - percentage of completion), que consiste no reconhecimento das receitas conforme andamento de obra. 
Contudo, neste estudo focaremos no estudo de Fluxo de Caixa dos projetos imobiliários, visto que a analise de viabilidade do projeto se dá pelo cash flow

\section{Estudo de Viabilidade Imobiliária}

Com o intuito de avaliar a viabilidade de um projeto imobiliário, a primeira etapa se dá através do fluxo de caixa descontado. Considera-se premissas como VGV, custo de obra, pagamento do terreno, despesas gerenciais e as receitas do financiamento e da velocidade de vendas.

O Volume Geral Vendas (VGV) é a receita total do empreendimento, ou seja, preço de venda $x$ total de unidades do empreendimento.

O VPL do empreendimento é determinado pelo somatório dos fluxos de caixa do VGV subtraído pelas despesas, descontado o custo de oportunidade do capital (WACC).

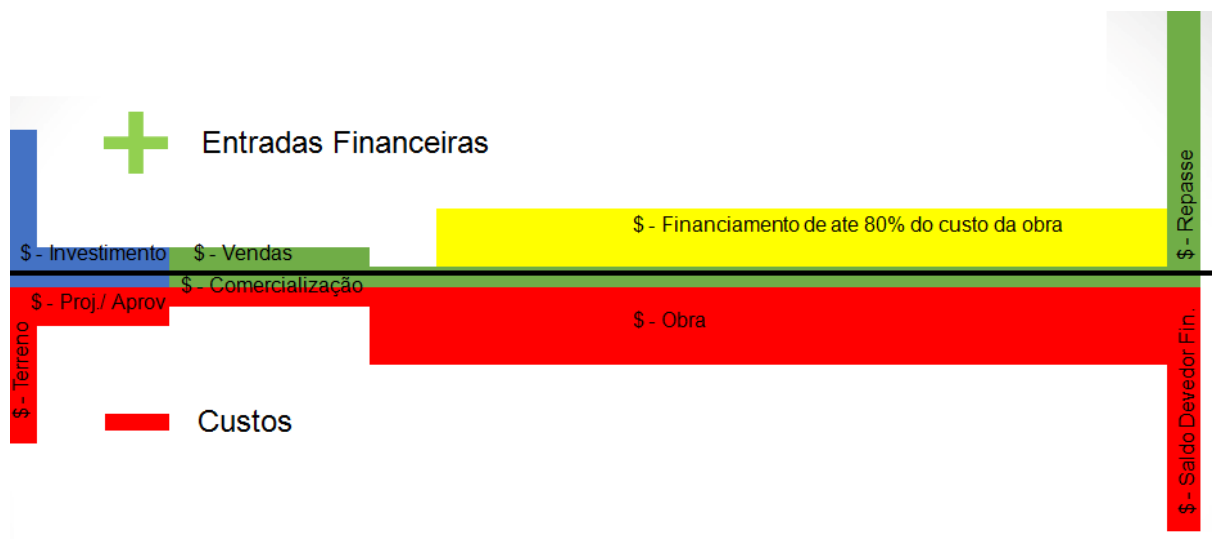

Figura 5: Fluxo de Caixa Imobiliário - Fonte: ABRAINC

É analisado também a TIR (taxa interna de retorno) e a margem VPL, que é o VPL sobre o VGV do empreendimento. Este indicador é importante, pois os projetos do setor são muito alavancados e a TIR por si só pode apresentar algum tipo de viés.

Não será avaliada neste trabalho a decisão de compra do terreno e da opção do lançamento. Tal estudo objetiva avaliar os possíveis riscos financeiros do projeto imobiliário que será disponibilizado para a venda. 


\section{4 \\ Modelagem e Resultados}

O estudo visa elaborar quatro cenários do mercado imobiliário e avaliar os resultados dos mesmos. O objetivo é mensurar os riscos do negócio ao longo do ciclo imobiliário.

\section{1.}

Premissas do modelo

Este trabalho apresentará uma análise de sensibilidade de um projeto imobiliário residencial localizado na área da zona oeste do Rio de Janeiro, considerando quatro cenários: base, pessimista, otimista e stress.

O empreendimento terá 260 unidades autônomas e suas datas de lançamento e entrega serão, respectivamente, janeiro de 2014 e abril de 2016 . O volume geral de vendas (VGV) para este projeto é de $R \$ 109,9 \mathrm{MM}$.

Segue o resumo do empreendimento na tabela 1 
Tabela 1: Resumo do Empreendimento analisado - Fonte elaboração própria

\begin{tabular}{|l|r|}
\hline \multicolumn{2}{|c|}{ RESUMO EMPREENDIMENTO } \\
\hline Tipo & Residencial \\
\hline Unidades & 260 \\
\hline VGV & jan/14 \\
\hline Lançamento & $\mathrm{abr} / 16$ \\
\hline Entrega & 16.313 \\
\hline \multicolumn{2}{|c|}{ DESPESAS em R\$MM } \\
\hline Terreno (\$) & 48.928 \\
\hline Custos de Obra & 9.014 \\
\hline Vendas & 913 \\
\hline Desp. Comp. Terreno & 684 \\
\hline Desp. Incorporação & 6.596 \\
\hline Impostos & 365 \\
\hline Gerenciamento & 82.813 \\
\hline Total Despesas &
\end{tabular}

Não haverá permuta física e financeira na aquisição do terreno. Ou seja, o pagamento dos $\mathrm{R} \$ 16,3 \mathrm{MM}$ ocorreu em dinheiro em janeiro de 2014 independentemente da receita e ou das vendas das unidades autônomas do projeto.

Além do terreno, a incorporadora incorre com despesas de vendas que são os gastos com corretagem, marketing, construção de stand. Todos estes desembolsos ocorrem antes do financiamento à produção e do lançamento do projeto.

As despesas complementares ao terreno são eventuais desembolsos de legalização do terreno junto aos órgãos competentes e pequenas obras antes da realização do lançamento.

As despesas de incorporação correspondem às despesas jurídicas, contratação dos seguranças para o terreno e de gerenciamento são despesas relacionadas à gestão financeira.

Os impostos cobrados em uma incorporação imobiliária são PIS, COFINS, CSLL e IRPJ. Este projeto adotará o regime de Lucro Presumido, e desta forma a alíquota cobrada sobre as vendas de unidades imobiliárias é $3,65 \%$ (PIS/COFINS). O Imposto de Renda (25\%) e a Contribuição Social sobre Lucro Líquido (9\%) são calculados sob uma base de $8 \%$ da Receita Líquida de Venda. 
A incorporadora tem um total de despesas no valor de $R \$ 82,8 \mathrm{MM}$ antes do lançamento. Isto representa $75 \%$ do VGV do empreendimento, deixando pouca margem para eventuais aumentos de despesas.

Durante a fase de obras, as parcelas serão divididas igualmente pelos meses que antecedem a entrega. As parcelas pré-habite-se, portanto, são constates. Após a entrega do empreendimento, não haverá parcelamento do valor do imóvel. O promitente comprador deverá realizar uma quitação com recursos próprios ou um financiamento no ato da aquisição. A incorporadora não realizará financiamentos diretos.

Diante dos custos e parâmetros citados acima, a análise de sensibilidade será realizada em quatro cenários onde a velocidade de vendas, a taxa de distrato e seu percentual de retenção e o desconto sobre o preço do bem serão as variáveis dependentes do estudo. Tais variáveis impactarão na Margem VPL, cujo gatilho para lançamento é de $15 \%$.

Segue, portanto, um resumo das variáveis em seus respectivos cenários:

Tabela 2: Resumo dos Cenários da Análise de Sensibilidade

\begin{tabular}{|c|c|c|c|c|}
\cline { 2 - 5 } \multicolumn{1}{c|}{} & Base & Otimista & Pessimista & Stress \\
\hline Vel Vendas (meses) & 65 & 28 & 65 & 65 \\
\hline Taxa de Distrato (\%) & 0 & 0 & 30 & 0 \\
\hline Retenção do Distrato (\%) & 0 & 0 & 50 & 0 \\
\hline Taxa de Desconto (\%) & 5 & 0 & 20 & 40 \\
\hline
\end{tabular}

4.2.

Custo médio ponderado de capital

O custo médio ponderado de capital (WACC) é obtido a partir da composição do capital que financia a empresa (capital próprio e de terceiros), ponderado por seus pesos (participações), e respectivos custos. Do custo da dívida extrai-se o seu benefício fiscal quando no Regime do Lucro Real, como o regime adotado é o do Lucro Presumido, este benefício não será capturado.

\footnotetext{
${ }^{1}$ Quando o regime de tributação é o Lucro Real, onde a base de cálculo do IR e
} CSLL é o EBIT, toda despesa paga a título de juros gera um benefício fiscal à empresa ao reduzir o lucro tributável e consequentemente o valor pago com os impostos federais. 


$$
W A C C=K d R /(R+5)+K e S /(R+5)
$$

A composição do capital se dará por $43 \%$ de capital de terceiros (B) e de $57 \%$ de capital próprio (S). O Kd real foi estabelecido como $10,00 \%$ a.a. descontado à inflação considerada como centro da meta estabelecida pelo governo, de $4,5 \%$ a.a., por tratar-se de projeto de longo prazo. O custo de $10 \%$ a.a. segue o custo de linhas de crédito obtidas pela empresa, comparando os demais financiamentos contratados pelas instituições financeiras que ofertam a modalidade de Financiamento à Produção.

O Ke é obtido seguindo a fórmula do CAPM²:

$$
\text { Ke }=R f+\beta(R m-R f)+\text { Risco Pais }
$$

Onde:

$\mathrm{Rf}=$ taxa livre de risco (Risk Free) e considerado como média aritmética do título da dívida norte-americana dos últimos 10 anos (5,31\% nominal) descontado à inflação, CPI (Consumer Price Index), de mesmo período (2,38\%). O Rf real encontrado é igual a 2,96\%.

$\beta=$ coeficiente de risco e o que foi utilizado é o do setor imobiliário (Real Estate (General/Diversified) e da ordem de 0,99. Como o projeto está alavancado com $43 \%$ de dívida, será utilizado o $\beta$ alavancado na mesma proporção.

$(\mathrm{Rm}-\mathrm{Rf})=$ prêmio livre de risco, parcela de juros cobrada pelo mercado para assumir algum risco na tentativa de obter uma remuneração acima do risco livre (Rf). O prêmio de risco considerado foi a média aritmética mais longa (19282015) do prêmio de risco americano (Stocks-T.Bonds), para que sejam capturados diversos ciclos econômicos, crises e períodos de stress. O valor obtido é de $6,25 \%$.

Neste caso o cálculo do WACC é dado por:

$$
W A C C=K d(1-T) B /(B+5)+K e S /(B+5)
$$

\footnotetext{
${ }^{2}$ Capital Market Asset Market (CAPM)
} 
Risco País = parcela de risco considerada para ajustar o modelo ao mercado onde o projeto será realizado, neste caso o Brasil. O valor é obtido do índice $\mathrm{EMBI}+$, no modelo considerando a média do índice para o ano de 2015, de $3,55 \%$.

Desta forma o Ke é $15,36 \%$ a.a., o Kd é 5,26\% a.a. e o WACC é $11,02 \%$ a.a.. O WACC é a taxa utilizada para descontar os fluxos de caixa futuros à valor presente para encontrar o VPL e margem VPL.

Tabela 3: Cálculo do WACC

\begin{tabular}{|l|c|}
\hline WACC & $\mathbf{1 1 , 0 2} \%$ \\
\hline Kd - Real & $\mathbf{5 , 2 6 \%}$ \\
\hline Ke - Real & $\mathbf{1 5 , 3 6 \%}$ \\
\hline RF real & $\mathbf{2 , 9 6 \%}$ \\
beta desalavancado & 0,99 \\
dívida/ capital próprio & $43 \%$ \\
beta alavancado & 1,42 \\
Prêmio Risco (RM-RF) & $6,25 \%$ \\
Risco Brasil & $3,55 \%$ \\
\hline
\end{tabular}

\section{3.}

Cenário Base

Ao realizar a viabilidade do projeto, o cenário base é o reflexo do mercado que precede o lançamento. A velocidade de vendas e o preço do imóvel, variáveis que impactam diretamente o caixa do projeto, são determinados conforme a demanda vigente. Seguem as premissas deste cenário na Tabela 4. 
Tabela 4: Premissas do Cenário Otimista - Fonte: Elaboração Própria

\begin{tabular}{|l|r|}
\hline \multicolumn{2}{|c|}{ PARAMETROS } \\
\hline$\%$ Financiamento Obra & $70 \%$ \\
\hline$\%$ Equity & $30 \%$ \\
\hline Pagamento Cliente Obra & $30 \%$ \\
\hline Taxa de Juros Fin. Construção & $10 \%$ \\
\hline Taxa de Desconto sobre Vendas & $10 \%$ \\
\hline Taxa de Retenção de Distrato & $0 \%$ \\
\hline Taxa de Distrato & $0 \%$ \\
\hline Unidades & 260 \\
\hline Lançamento & jan-14 \\
\hline Entrega & abr-16 \\
\hline RESUMO DO EMPREENDIMENTO (em R\$M) \\
\hline VGV & 109.931 .781 \\
\hline Terreno (\$) & 16.312 .779 \\
\hline Custos de Obra & 48.927 .506 \\
\hline Vendas & 9.014 .406 \\
\hline Desp.Complementares Terreno & 913.322 \\
\hline Desp. Incorporação & 684.388 \\
\hline Impostos & 6.595 .907 \\
\hline Gerenciamentos & 365.000 \\
\hline Total Despesas & 82.813 .307 \\
\hline
\end{tabular}

O cenário base considera que $70 \%$ do empreendimento será vendido até a conclusão da obra. Os outros $30 \%$ serão vendidos em três anos após a entrega das unidades autônomas. Portanto, a curva de vendas durará 65 meses a contar da data de lançamento. 
Tabela 5: Velocidade de Vendas Cenário Base

\begin{tabular}{|c|c|c|c|c|c|}
\hline Meses & Base & Acumulado & Meses & Base & Acumulado \\
\hline $\mathrm{jan} / 14$ & $28 \%$ & $28 \%$ & set/16 & $0,8 \%$ & $73 \%$ \\
\hline $\mathrm{fev} / 14$ & $7 \%$ & $35 \%$ & out/16 & $0,8 \%$ & $74 \%$ \\
\hline $\mathrm{mar} / 14$ & $7 \%$ & $42 \%$ & nov/16 & $0,8 \%$ & $75 \%$ \\
\hline$a b r / 14$ & $4 \%$ & $46 \%$ & $\mathrm{dez} / 16$ & $0,8 \%$ & $76 \%$ \\
\hline $\mathrm{mai} / 14$ & $4 \%$ & $49 \%$ & $\mathrm{jan} / 17$ & $0,8 \%$ & $77 \%$ \\
\hline jun/14 & $2 \%$ & $51 \%$ & fev/17 & $0,8 \%$ & $78 \%$ \\
\hline $\mathrm{jul} / 14$ & $2 \%$ & $53 \%$ & $\mathrm{mar} / 17$ & $0,8 \%$ & $78 \%$ \\
\hline ago/14 & $1 \%$ & $55 \%$ & $\mathrm{abr} / 17$ & $0,8 \%$ & $79 \%$ \\
\hline set/14 & $1 \%$ & $56 \%$ & mai/17 & $0,8 \%$ & $80 \%$ \\
\hline out/14 & $1 \%$ & $57 \%$ & jun/17 & $0,8 \%$ & $81 \%$ \\
\hline nov/14 & $1 \%$ & $57 \%$ & $\mathrm{jul} / 17$ & $0,8 \%$ & $82 \%$ \\
\hline $\mathrm{dez} / 14$ & $1 \%$ & $58 \%$ & ago/17 & $0,8 \%$ & $83 \%$ \\
\hline jan/15 & $1 \%$ & $59 \%$ & set/17 & $0,8 \%$ & $83 \%$ \\
\hline fev/15 & $1 \%$ & $60 \%$ & out/17 & $0,8 \%$ & $84 \%$ \\
\hline $\mathrm{mar} / 15$ & $1 \%$ & $60 \%$ & nov/17 & $0,8 \%$ & $85 \%$ \\
\hline$a b r / 15$ & $1 \%$ & $61 \%$ & $\mathrm{dez} / 17$ & $0,8 \%$ & $86 \%$ \\
\hline $\mathrm{mai} / 15$ & $1 \%$ & $62 \%$ & jan/18 & $0,8 \%$ & $87 \%$ \\
\hline jun/15 & $1 \%$ & 62\% & fev/18 & $0,8 \%$ & $87 \%$ \\
\hline$j u l / 15$ & $1 \%$ & $62 \%$ & $\mathrm{mar} / 18$ & $0,8 \%$ & $88 \%$ \\
\hline $\mathrm{ago} / 15$ & $1 \%$ & $63 \%$ & $a b r / 18$ & $0,8 \%$ & $89 \%$ \\
\hline set/15 & $1 \%$ & $64 \%$ & mai/18 & $0,8 \%$ & $90 \%$ \\
\hline out/15 & $1 \%$ & $64 \%$ & jun/18 & $0,8 \%$ & $91 \%$ \\
\hline nov/15 & \begin{tabular}{l|l}
$\%$ & \\
$10 \%$
\end{tabular} & $65 \%$ & $\mathrm{jul} / 18$ & $0,8 \%$ & $92 \%$ \\
\hline & $1 \%$ & $66 \%$ & ago/18 & $0,8 \%$ & $92 \%$ \\
\hline dez/ls & $1 \%$ & $67 \%$ & set/18 & $0,8 \%$ & $93 \%$ \\
\hline jan/16 & $1 \%$ & $67 \%$ & out/18 & $0,8 \%$ & $94 \%$ \\
\hline $\mathrm{fev} / 16$ & $1 \%$ & $68 \%$ & nov/18 & $0,8 \%$ & $95 \%$ \\
\hline mar/16 & $1 \%$ & $69 \%$ & $\mathrm{dez} / 18$ & $0,8 \%$ & $96 \%$ \\
\hline $\mathrm{abr} / 16$ & $1 \%$ & $70 \%$ & $\mathrm{jan} / 19$ & $0,8 \%$ & $97 \%$ \\
\hline mai/16 & $0 \%$ & $70 \%$ & fev/19 & $0,8 \%$ & $97 \%$ \\
\hline jun/16 & $0,8 \%$ & $71 \%$ & $\mathrm{mar} / 19$ & $0,8 \%$ & $98 \%$ \\
\hline jul/16 & $0,8 \%$ & $72 \%$ & $a b r / 19$ & $0,8 \%$ & $99 \%$ \\
\hline ago/16 & $0,8 \%$ & $73 \%$ & mai/19 & $0,8 \%$ & $100 \%$ \\
\hline
\end{tabular}




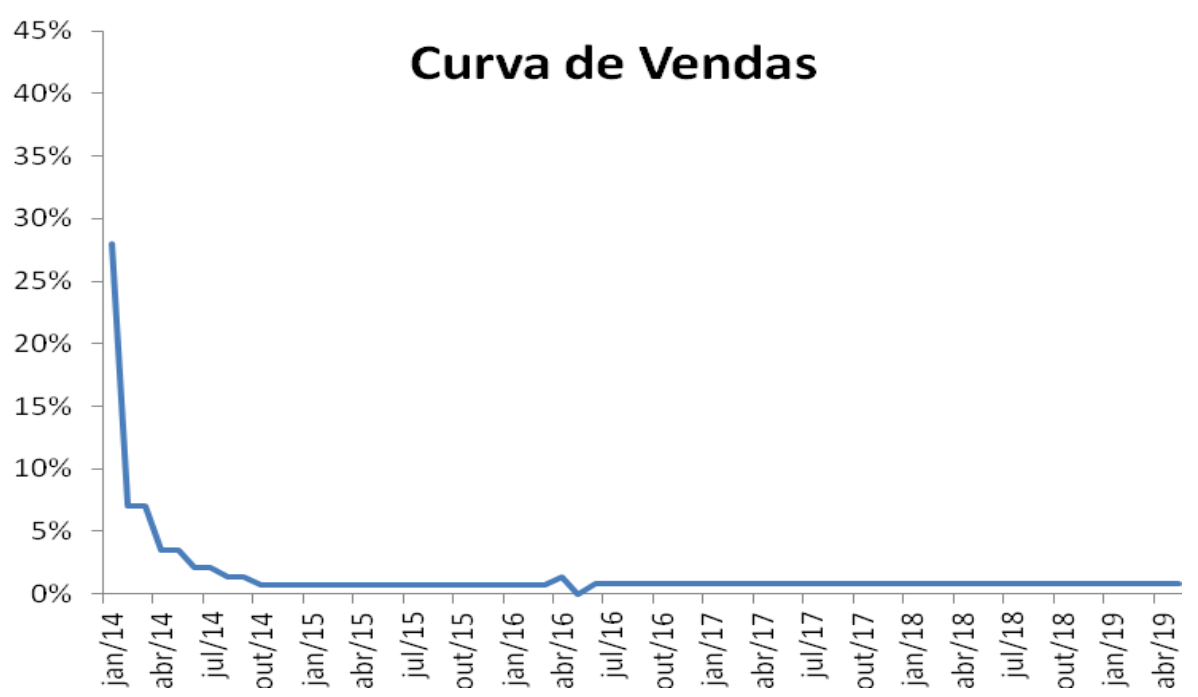

Figura 6: Velocidade de Vendas no Cenário Base - Fonte: Elaboração

\section{Própria}

Verifica-se que o empreendimento terá $70 \%$ do seu custo de obra financiado, caso cumpra com as exigências de gatilhos de vendas, que neste caso é $30 \%$ e contratação de seguros. A taxa de juros cobrada pelo banco será de $10 \%$ a.a e a fim de simplificar o estudo, o pagamento dos recursos ocorrerá em uma única parcela em maio de 2016.

Em virtude dos trâmites burocráticos, o financiamento será contratado em janeiro de 2015. Visto que no momento da contratação do financiamento as vendas estarão em 59\%, o valor liberado será proporcional ao cronograma de obra executado até o momento. A partir da liberação do primeiro tranche de financiamento, o banco disponibilizará mensalmente os recursos conforme andamento de obra auferido pela engenharia da instituição financeira.

Neste cenário não ocorrerá distrato e um desconto de $10 \%$ na tabela de vendas. Os clientes efetuarão o pagamento de $30 \%$ da sua unidade durante as obras e o restante na entrega do empreendimento.

Após a elaboração do fluxo de caixa deste cenário, obtem-se um VPL de $\mathrm{R} \$ 23.472 \mathrm{MM}$, atribuindo ao projeto atratividade aos acionistas e geração de valor. A Margem VPL (VPL/VGV do empreendimento) de 21,4\% é acima do gatilho determinado pelo incorporador, que é de $15 \%$, confirmando a geração do valor incremental. 
4.4.

Cenário Otimista

Este cenário todo o empreendimento é vendido até a sua entrega e não há nenhuma desistência e desconto sobre o preço. As premissas são as mesmas da Tabela 2, apresentada no Cenário Base.

Tabela 6: Velocidade de Vendas do Cenário Otimista - Fonte: Elaboração Própria

\begin{tabular}{|c|c|c|}
\hline Meses & Otimista & Acumulado \\
\hline jan/14 & $40 \%$ & $40 \%$ \\
\hline fev/14 & $10 \%$ & $50 \%$ \\
\hline mar/14 & $10 \%$ & $60 \%$ \\
\hline abr/14 & $5 \%$ & $65 \%$ \\
\hline mai/14 & $5 \%$ & $70 \%$ \\
\hline jun/14 & $3 \%$ & $73 \%$ \\
\hline jul/14 & $3 \%$ & $76 \%$ \\
\hline ago/14 & $2 \%$ & $78 \%$ \\
\hline set/14 & $2 \%$ & $80 \%$ \\
\hline out/14 & $1 \%$ & $81 \%$ \\
\hline nov/14 & $1 \%$ & $82 \%$ \\
\hline dez/14 & $1 \%$ & $83 \%$ \\
\hline jan/15 & $1 \%$ & $84 \%$ \\
\hline fev/15 & $1 \%$ & $85 \%$ \\
\hline mar/15 & $1 \%$ & $86 \%$ \\
\hline abr/15 & $1 \%$ & $87 \%$ \\
\hline mai/15 & $1 \%$ & $88 \%$ \\
\hline jun/15 & $1 \%$ & $89 \%$ \\
\hline jul/15 & $1 \%$ & $90 \%$ \\
\hline ago/15 & $1 \%$ & $91 \%$ \\
\hline set/15 & $1 \%$ & $92 \%$ \\
\hline out/15 & $1 \%$ & $93 \%$ \\
\hline nov/15 & $1 \%$ & $94 \%$ \\
\hline dez/15 & $1 \%$ & $95 \%$ \\
\hline jan/16 & $1 \%$ & $96 \%$ \\
\hline fev/16 & $1 \%$ & $97 \%$ \\
\hline mar/16 & $1 \%$ & $98 \%$ \\
\hline abr/16 & $2 \%$ & $100 \%$ \\
\hline & & \\
\hline
\end{tabular}

Comparando o cenário base com o otimista verifica-se a diferença de velocidade de vendas: 


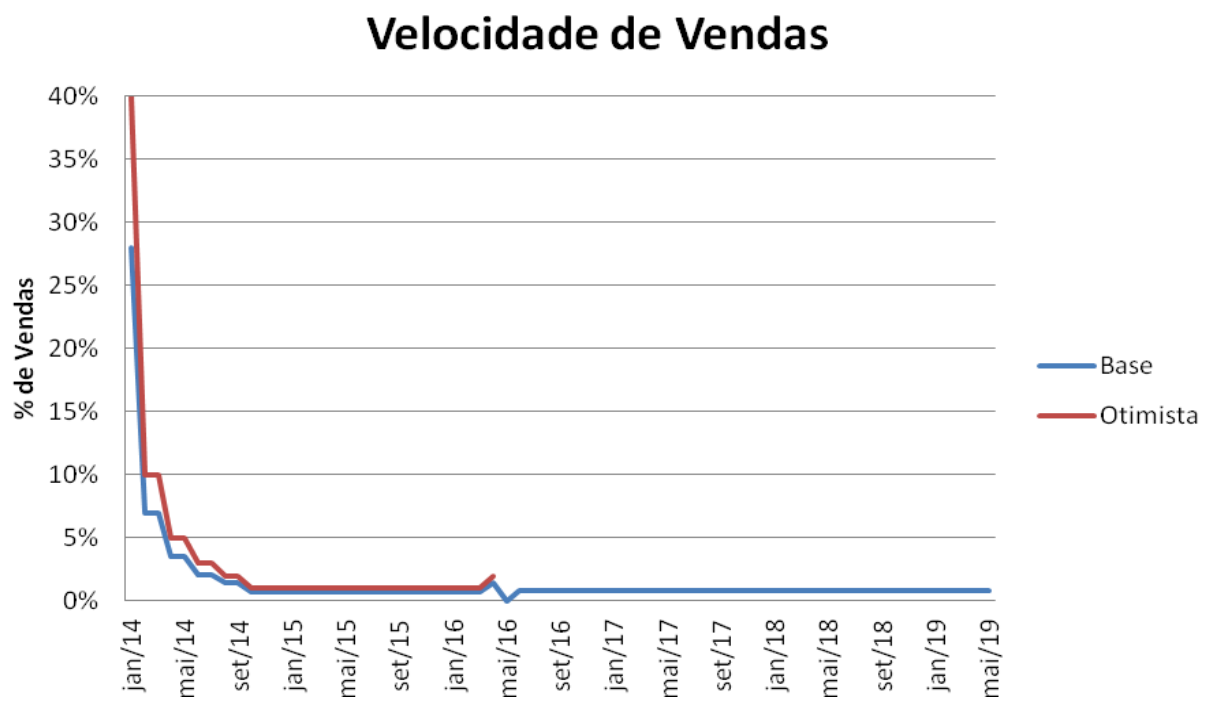

Figura 7: Comparativo de Velocidade de Vendas entre os Cenários Otimista e Base

Esta curva beneficia o incorporador, pois no momento da entrega do empreendimento, $100 \%$ das unidades estarão vendidas, desonerando a empresa de assumir despesas como condomínio, IPTU e manutenção das unidades em estoque. Além disso, verifica-se que nesta curva, o gatilho para a liberação do financiamento a atingida no mês 1 do lançamento.

Não será aplicado desconto sobre as vendas, ou seja, a margem do lucro será mantida e não haverá distratos no projeto. O repasse, ou seja, a contratação do financiamento imobiliário dos promitentes compradores durará apenas 1 mês, permitindo que todos os clientes tenham liquidado o seu saldo junto a incorporadora 30 dias após a entrega do empreendimento.

Já no lançamento o projeto atinge o mínimo de comercialização estabelecido pela instituição bancária e os recursos provenientes ao financiamento do empreendimento será liberado assim que houver a contratação do crédito.

Após a elaboração do fluxo de caixa deste cenário, obtem-se um VPL de R\$ 30.5 MM positivos, a Margem VPL (VPL/VGV do empreendimento) de 27,8\%, agregando valor aos acionistas. 


\section{5.}

\section{Cenário Pessimista}

O cenário pessimista possui uma velocidade de vendas de $50 \%$ das unidades autônomas até a entrega do empreendimento. Contudo, com a conclusão do empreendimento, $30 \%$ dos promitentes compradores desistem, optando pelo distrato. A incorporadora passa a adotar taxas de desconto a fim de revender o seu recente estoque. Após a entrega, os distratos e os descontos concedidos, o empreendimento é totalmente vendido em 36 meses, totalizando 65 meses.

Os parâmetros deste novo cenário são apresentados na Tabela 7.

Tabela 7: Premissas do Cenário Pessimista - Fonte: Elaboração Própria

\begin{tabular}{|l|r|}
\hline \multicolumn{2}{|c|}{ PARAMMETROS } \\
\hline$\%$ Financiamento Obra & $70 \%$ \\
\hline$\%$ Equity & $30 \%$ \\
\hline Pagamento Cliente Obra & $30 \%$ \\
\hline Taxa de Juros Fin. Construção & $10 \%$ \\
\hline Taxa de Desconto sobre Vendas & $20 \%$ \\
\hline Taxa de Retenção de Distrato & $30 \%$ \\
\hline Taxa de Distrato & $50 \%$ \\
\hline Unidades & 260 \\
\hline Lançamento & jan-14 \\
\hline Entrega & $a b r-16$ \\
\hline \multicolumn{1}{|c|}{ RESUMO DO EMPREENDIMENTO (em R\$M) } \\
\hline VGV & 109.932 \\
\hline Terreno (\$) & 16.313 \\
\hline Custos de Obra & 48.928 \\
\hline Vendas & 9.014 \\
\hline Desp.Complementares Terreno & 913 \\
\hline Desp. Incorporação & 684 \\
\hline Impostos & 6.596 \\
\hline Gerenciamentos & 365 \\
\hline Total Despesas & 82.813 \\
\hline
\end{tabular}

A fim de facilitar a análise, todos os clientes assinarão distrato aceitando a retenção de $50 \%$ do valor pago. Não serão consideradas rescisões judiciais e restituições parceladas oriundas da desistência da unidade. 
Diante dos distratos, a velocidade de vendas pode ser verificada através da tabela abaixo:

Tabela 8: Velocidade de Vendas do Cenário Pessimista

\begin{tabular}{|c|c|c|c|c|c|}
\hline Meses & Pessimista & Acumulado & Meses & Pessimista & Acumulado \\
\hline jan/14 & $20,0 \%$ & $20 \%$ & set/16 & $1,8 \%$ & $42 \%$ \\
\hline fev/14 & $5,0 \%$ & $25 \%$ & out/16 & $1,8 \%$ & $44 \%$ \\
\hline mar/14 & $5,0 \%$ & $30 \%$ & nov/16 & $1,8 \%$ & $46 \%$ \\
\hline$a b r / 14$ & $2,5 \%$ & $33 \%$ & $\mathrm{dez} / 16$ & $1,8 \%$ & $48 \%$ \\
\hline $\mathrm{mai} / 14$ & $2,5 \%$ & $35 \%$ & jan/17 & $1,8 \%$ & $49 \%$ \\
\hline jun/14 & $1,5 \%$ & $37 \%$ & fev/17 & $1,8 \%$ & $51 \%$ \\
\hline $\mathrm{jul} / 14$ & $1,5 \%$ & $38 \%$ & $\mathrm{mar} / 17$ & $1,8 \%$ & $53 \%$ \\
\hline ago/14 & $1,0 \%$ & $39 \%$ & $a b r / 17$ & $1,8 \%$ & $55 \%$ \\
\hline set/14 & $1,0 \%$ & $40 \%$ & $\mathrm{mai} / 17$ & $1,8 \%$ & $57 \%$ \\
\hline out/14 & $0,5 \%$ & $41 \%$ & jun/17 & $1,8 \%$ & $58 \%$ \\
\hline nov/14 & $0,5 \%$ & $41 \%$ & jul/17 & $1,8 \%$ & $60 \%$ \\
\hline $\mathrm{dez} / 14$ & $0,5 \%$ & $42 \%$ & ago/17 & $1,8 \%$ & $62 \%$ \\
\hline jan/15 & $0,5 \%$ & $42 \%$ & set/17 & $1,8 \%$ & $64 \%$ \\
\hline $\mathrm{fev} / 15$ & $0,5 \%$ & $43 \%$ & out/17 & $1,8 \%$ & $66 \%$ \\
\hline $\mathrm{mar} / 15$ & $0,5 \%$ & $43 \%$ & nov/17 & $1,8 \%$ & $68 \%$ \\
\hline$a b r / 15$ & $0,5 \%$ & $44 \%$ & $\mathrm{dez} / 17$ & $1,8 \%$ & $69 \%$ \\
\hline mai/15 & $0,5 \%$ & $44 \%$ & jan/18 & $1,8 \%$ & $71 \%$ \\
\hline jun/15 & $0,5 \%$ & $45 \%$ & $\mathrm{fev} / 18$ & $1,8 \%$ & $73 \%$ \\
\hline $\mathrm{jul} / 15$ & $0,5 \%$ & $45 \%$ & mar/18 & $1,8 \%$ & $75 \%$ \\
\hline $\mathrm{ago} / 15$ & $0,5 \%$ & $46 \%$ & $a b r / 18$ & $1,8 \%$ & $77 \%$ \\
\hline set/15 & $0,5 \%$ & $46 \%$ & mai/18 & $1,8 \%$ & $78 \%$ \\
\hline out/15 & $0,5 \%$ & $\frac{40 \%}{47 \%}$ & jun/18 & $1,8 \%$ & $80 \%$ \\
\hline nov/15 & $0,5 \%$ & $\frac{41 / 0}{170 /}$ & jul/18 & $1,8 \%$ & $82 \%$ \\
\hline $\mathrm{dez} / 15$ & $0.5 \%$ & 4170 & ago/18 & $1,8 \%$ & $84 \%$ \\
\hline jan/16 & |0,5\% & $40 \%$ & set/18 & $1,8 \%$ & $86 \%$ \\
\hline $\mathrm{fev} / 16$ & $0,5 \%$ & $48 \%$ & out/18 & $1,8 \%$ & $87 \%$ \\
\hline $\mathrm{mar} / 16$ & \begin{tabular}{l|}
, $5 \%$ \\
$0,5 \%$
\end{tabular} & $\frac{49 \%}{100 /}$ & nov/18 & $1,8 \%$ & $89 \%$ \\
\hline$a b r / 16$ & $1.0 \%$ & $49 \%$ & $\mathrm{dez} / 18$ & $1,8 \%$ & $91 \%$ \\
\hline mai/16 & \begin{tabular}{|c|}
$1,0 \%$ \\
$-15,0 \%$
\end{tabular} & & $\mathrm{jan} / 19$ & $1,8 \%$ & $93 \%$ \\
\hline jun/16 & & & fev/19 & $1,8 \%$ & $95 \%$ \\
\hline $\mathrm{jul} / 16$ & $\frac{1,0 \%}{100 /}$ & $3 / \%$ & mar/19 & $1,8 \%$ & $96 \%$ \\
\hline $\mathrm{ago} / 16$ & $1,0 \%$ & & $a b r / 19$ & $1,8 \%$ & $98 \%$ \\
\hline & $1,8 \%$ & $40 \%$ & mai/19 & $1,8 \%$ & $100 \%$ \\
\hline
\end{tabular}

Ao realizar o comparativo no entre os cenários anteriomente apresentados, verifica-se uma queda acentuada no percentual vendido, sendo retomada após a entrega: 


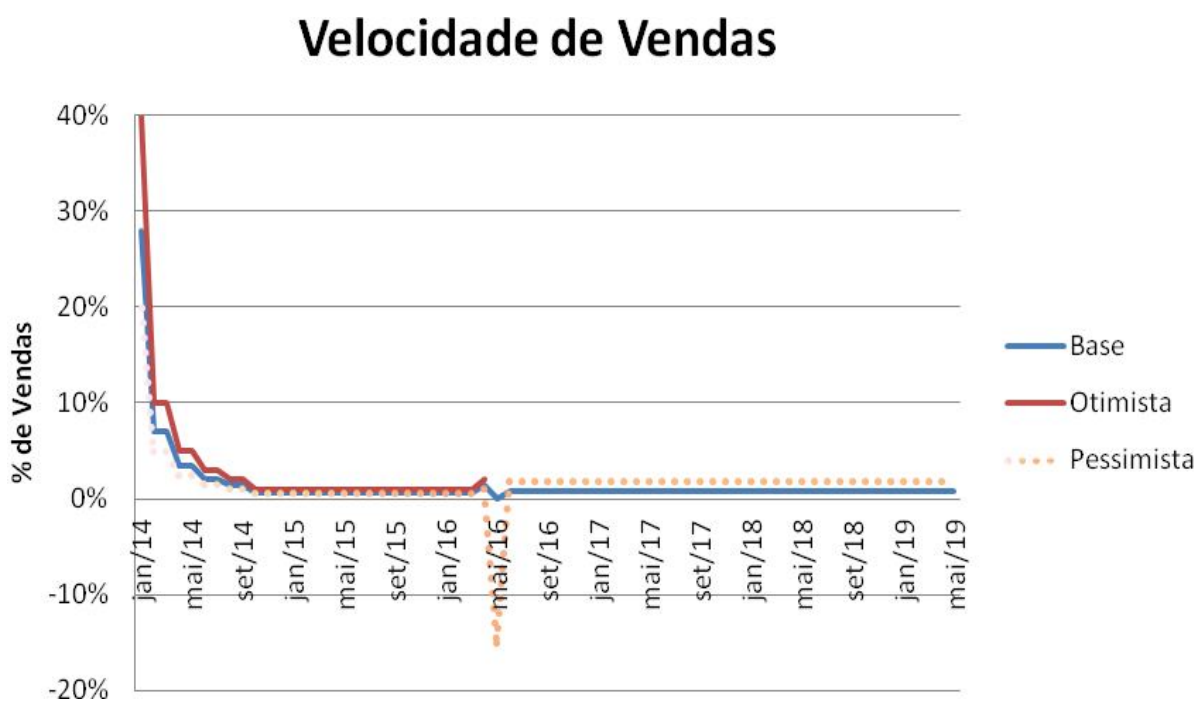

Figura 8: Comparativo da Velocidade de Vendas entre os Cenários Otimista, Base e Pessimista - Fonte: Elaboração Própria.

Após a elaboração do fluxo de caixa deste cenário, obtem-se um VPL de $\mathrm{R} \$ 13.08 \mathrm{MM}$ positivos, a Margem VPL (VPL/VGV do empreendimento) de $11,9 \%$.

Apesar do VPL positivo, a margem VPL está abaixo do gatilho determinado pelos acionistas, inviabilizando o lançamento. Os acionistas poderiam postergar o investimento ou optar pela mudança dos parâmetros do produto a fim de atingir os $15 \%$ de margem VPL.

\section{6.}

\section{Cenário de Stress}

O último cenário apresentado é o cenário de stress. O empreendimento atinge o gatilho das vendas para a liberação do financiamento bancário apenas quando a obra estiver concluída. Portanto, os acionistas são os únicos a financiar a obra tendo em vista que os recursos de vendas são insuficientes e financiamento banco não foi liberado. O desconto oferecido para acelerar as vendas chega a $40 \%$ 
Tabela 9: Premissas Cenário Stress

\begin{tabular}{|l|r|}
\hline \multicolumn{2}{|c|}{ PARAMETROS } \\
\hline$\%$ Financiamento Obra & $70 \%$ \\
\hline$\%$ Equity & $30 \%$ \\
\hline Pagamento Cliente Obra & $30 \%$ \\
\hline Taxa de Juros Fin. Construção & $10 \%$ \\
\hline Taxa de Desconto sobre Vendas & $40 \%$ \\
\hline Taxa de Retenção de Distrato & $0 \%$ \\
\hline Taxa de Distrato & $0 \%$ \\
\hline Unidades & 260 \\
\hline Lançamento & jan-14 \\
\hline Entrega & abr-16 \\
\hline \multicolumn{1}{|c|}{ RESUMO DO EMPREENDIMENTO (em R\$ MM) } \\
\hline VGV & 109.932 \\
\hline Terreno (\$) & 16.313 \\
\hline Custos de Obra & 48.928 \\
\hline Vendas & 9.014 \\
\hline Desp.Complementares Terreno & 913 \\
\hline Desp. Incorporação & 684 \\
\hline Impostos & 6.596 \\
\hline Gerenciamentos & 365 \\
\hline Total Despesas & 82.813 \\
\hline
\end{tabular}

Pode-se verificar a baixa velocidade de vendas na tabela 10 . 
Tabela 10: Velocidade de Venda no Cenário de Stress

\begin{tabular}{|c|c|c|c|c|c|}
\hline Meses & Stress & Acumulado & Meses & Stress & Acumulado \\
\hline $\mathrm{jan} / 14$ & $5,0 \%$ & $5 \%$ & set/16 & $1,9 \%$ & $38 \%$ \\
\hline fev/14 & $1,0 \%$ & $6 \%$ & out/16 & $1,9 \%$ & $40 \%$ \\
\hline $\mathrm{mar} / 14$ & $1,0 \%$ & $7 \%$ & nov/16 & $1,9 \%$ & $42 \%$ \\
\hline$a b r / 14$ & $1,0 \%$ & $8 \%$ & $\mathrm{dez} / 16$ & $1,9 \%$ & $44 \%$ \\
\hline mai/14 & $1,0 \%$ & $9 \%$ & jan/17 & $1,9 \%$ & $46 \%$ \\
\hline jun/14 & $1,0 \%$ & $10 \%$ & fev/17 & $1,9 \%$ & $48 \%$ \\
\hline $\mathrm{jul} / 14$ & $1,0 \%$ & $11 \%$ & $\mathrm{mar} / 17$ & $1,9 \%$ & $49 \%$ \\
\hline ago/14 & $1,0 \%$ & $12 \%$ & $a b r / 17$ & $1,9 \%$ & $51 \%$ \\
\hline set/14 & $1,0 \%$ & $13 \%$ & mai/17 & $1,9 \%$ & $53 \%$ \\
\hline out/14 & $1,0 \%$ & $14 \%$ & jun/17 & $1,9 \%$ & $55 \%$ \\
\hline nov/14 & $1,0 \%$ & $15 \%$ & jul/17 & $1,9 \%$ & $57 \%$ \\
\hline $\mathrm{dez} / 14$ & $1,0 \%$ & $16 \%$ & ago/17 & $1,9 \%$ & $59 \%$ \\
\hline jan/15 & $1,0 \%$ & $17 \%$ & set/17 & $1,9 \%$ & $61 \%$ \\
\hline fev/15 & $1,0 \%$ & $18 \%$ & out $/ 17$ & $1,9 \%$ & $63 \%$ \\
\hline $\mathrm{mar} / 15$ & $1,0 \%$ & $19 \%$ & nov/17 & $1,9 \%$ & $65 \%$ \\
\hline$a b r / 15$ & $1,0 \%$ & $20 \%$ & $\mathrm{dez} / 17$ & $1,9 \%$ & $67 \%$ \\
\hline mai/15 & $1,0 \%$ & $\frac{20 \%}{21 \%}$ & $\mathrm{jan} / 18$ & $1,9 \%$ & $69 \%$ \\
\hline jun/15 & $1.0 \%$ & $\frac{21 \%}{22 \%}$ & fev/18 & $1,9 \%$ & $71 \%$ \\
\hline $\mathrm{jul} / 15$ & $1,0 \%$ & $\frac{c<10}{23 \%}$ & mar/18 & $1,9 \%$ & $73 \%$ \\
\hline ago/15 & $1,0 \%$ & $\frac{20 \%}{24 \%}$ & $a b r / 18$ & $1,9 \%$ & $75 \%$ \\
\hline set/15 & $1.0 \%$ & $\frac{24 \%}{25 \%}$ & $\mathrm{mai} / 18$ & $1,9 \%$ & $77 \%$ \\
\hline out/15 & $10 \%$ & $201 \%$ & jun/18 & $1,9 \%$ & $79 \%$ \\
\hline nov/15 & $\frac{1,0 \%}{10 \%}$ & $20 \%$ & jul/18 & $1,9 \%$ & $81 \%$ \\
\hline $\mathrm{dez} / 15$ & $1,0 \%$ & $21 \%$ & ago/18 & $1,9 \%$ & $83 \%$ \\
\hline & $1,0 \%$ & $28 \%$ & set/18 & $1,9 \%$ & $84 \%$ \\
\hline & $0,5 \%$ & $29 \%$ & out/18 & $1,9 \%$ & $86 \%$ \\
\hline & $0,5 \%$ & $29 \%$ & nov/18 & $1,9 \%$ & $88 \%$ \\
\hline$\frac{\mathrm{mar} / 16}{\mathrm{abr} / 16}$ & $0,5 \%$ & $30 \%$ & dez/18 & $1,9 \%$ & $90 \%$ \\
\hline $\mathrm{abr} / 16$ & $0,5 \%$ & $30 \%$ & jan/19 & $1,9 \%$ & $92 \%$ \\
\hline mai/16 & $0,0 \%$ & $30 \%$ & fev/19 & $1,9 \%$ & $94 \%$ \\
\hline jun/16 & $1,9 \%$ & $32 \%$ & mar/19 & $1,9 \%$ & $96 \%$ \\
\hline jul/16 & $1,9 \%$ & $34 \%$ & $a b r / 19$ & $1,9 \%$ & $98 \%$ \\
\hline ago/16 & $1,9 \%$ & $36 \%$ & mai/19 & $1,9 \%$ & $100 \%$ \\
\hline
\end{tabular}




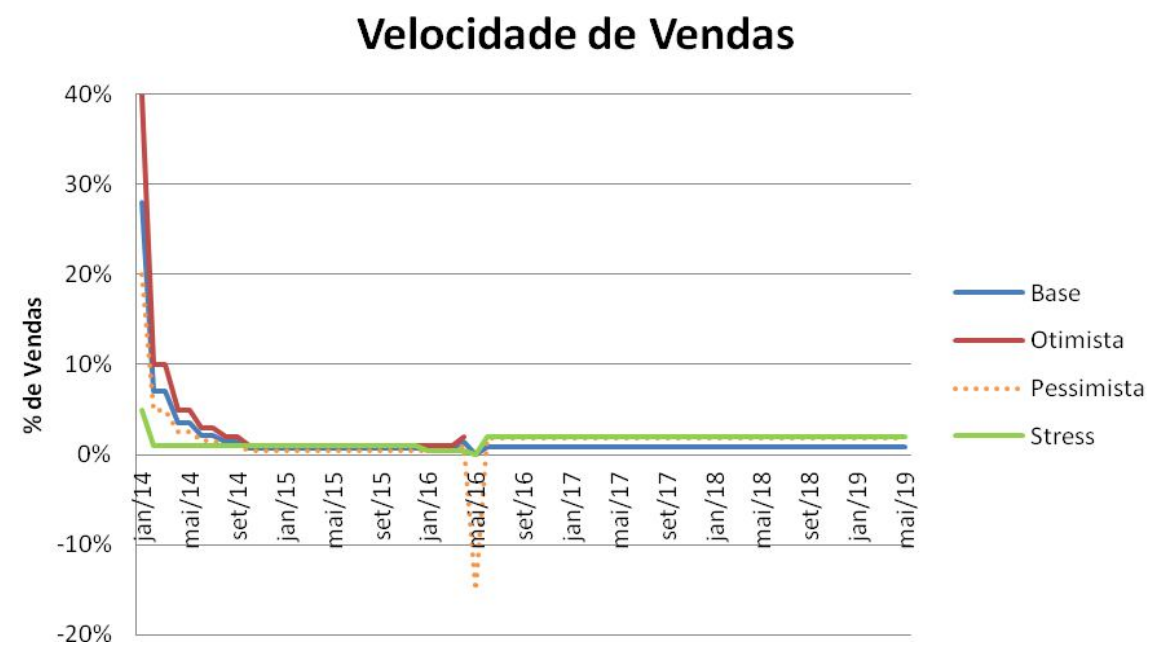

Figura 9: Comparativo da Velocidade de Vendas entre os Cenários Otimista, Base, Pessimista e Stress - Fonte: Elaboração Própria

O gráfico 9 mostra a comparação das velocidades das curvas de vendas dos quatro cenários.

Pode-se verificar que o nível de vendas do cenário de stress é permantemente baixo. Isto impacta diretamente o seu fluxo de caixa. $O$ desconto concedidido pelo incorporador de 10\% não foi capaz de impulsionar a venda.

Após a elaboração do fluxo de caixa deste cenário, obtem-se um VPL de $\mathrm{R} \$ 10.08 \mathrm{MM}$ negativos, a Margem VPL (VPL/VGV do empreendimento) de $9,2 \%$ negativos. Desta forma, os resultados do cenário de stress são muito desfavoráveis. O VPL negativo significa a destruição de valor do acionista, pois o projeto não remunera o seu custo de capital

As incorporadoras possuem 180 dias após o lançamento para desistir do negócio. Denunciar a incorporação significa não levar o projeto adiante, devolvendo os valores pagos para os clientes que adquiriram as unidades autônomas. Esta decisão pode ser tomada por diversos fatores, entre eles, o baixo nível de vendas. 


\title{
4.7.
}

Resumo da Análise de Sensibilidade

Após a análise de sensibilidade, é possível verificar que a mudança dos cenários impacta diretamente no resultado dos projetos. Os resultados dos indicadores de acordo com a expectativa de vendas, desistência e desconto constam na tabela 11 .

Tabela 11: Resultado da Análise de Sensibilidade

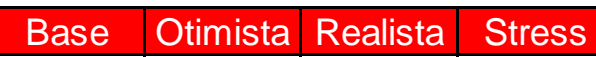

\begin{tabular}{|l|r|r|r|r|}
\hline Margem VPL (\%) & 21,4 & 27,8 & 11,9 & $-9,2$ \\
\hline VPL (MM de R\$) & 21 & 30 & 13 & -10 \\
\hline
\end{tabular}

\section{8. \\ Gerenciamento de Risco}

\begin{abstract}
O cálculo do Valor em Risco (ou VAR) é um método de se obter o valor esperado da máxima perda (ou pior perda) dentro de um horizonte de tempo com um intervalo de confiança. Portanto, visto que o ciclo imobiliário é suscetível aos indicadores econômicos, deve-se atribuir uma probabilidade de mudança de cenário ao longo da construção do projeto.

Após a análise de sensibilidade, serão atribuídas probabilidades de perdas e ganhos no cenário base. Foram atribuídas distribuições para as variáveis impactam diretamente o caixa: taxa de distrato, preço de venda e custo de construção.
\end{abstract}

\subsection{1.}

\section{Análise de Risco do Cenário Base}

Após a análise de sensibilidade, serão atribuídas probabilidades de perdas e ganhos no cenário base. Foram atribuídas distribuições para as variáveis impactam diretamente o caixa: taxa de distrato, preço de venda e custo de construção. 
Após a utilização do @Risk serão mostrados a seguir o resultado das atribuições das distribuições das variáveis citadas anteriormente.

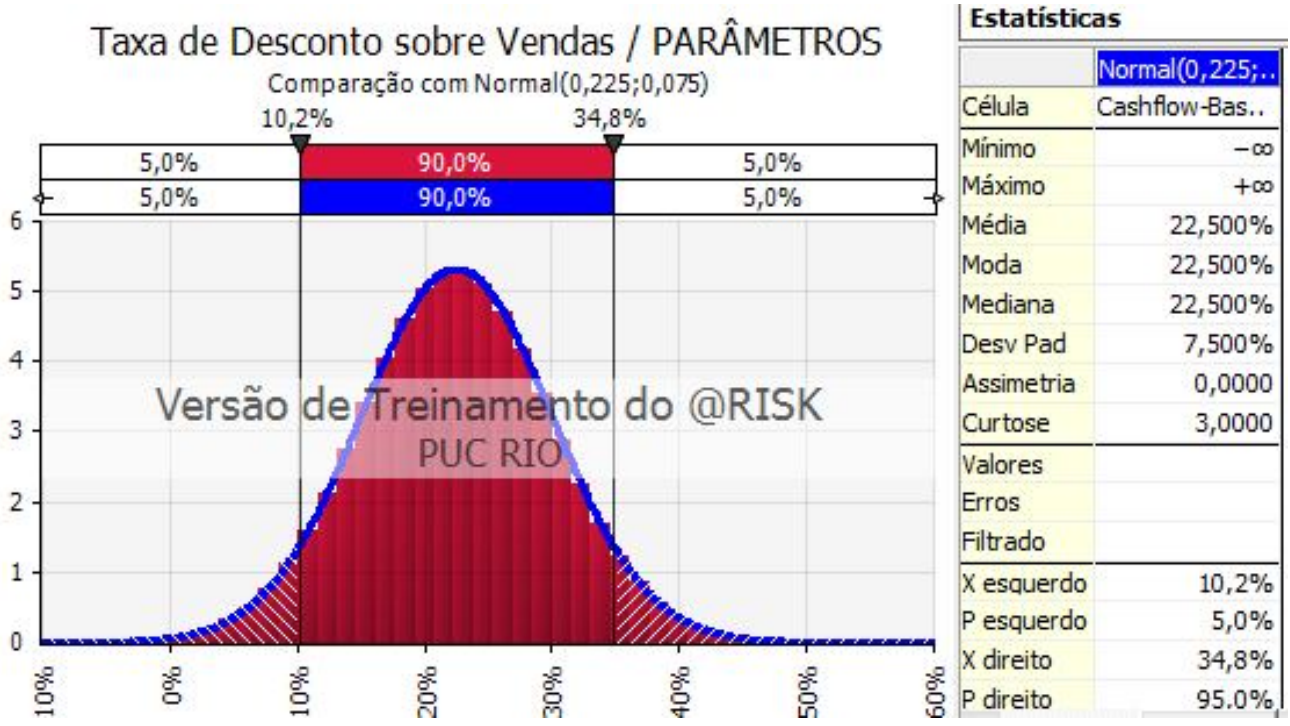

Figura 10: Distribuição Normal da Taxa de Desconto no Cenário Base

Atribuindo uma média de $22,5 \%$ e um desvio padrão de $7,5 \%$, verifica-se que existem $90 \%$ de chances dos descontos estarem entre $10,2 \%$ e $34,8 \%$.

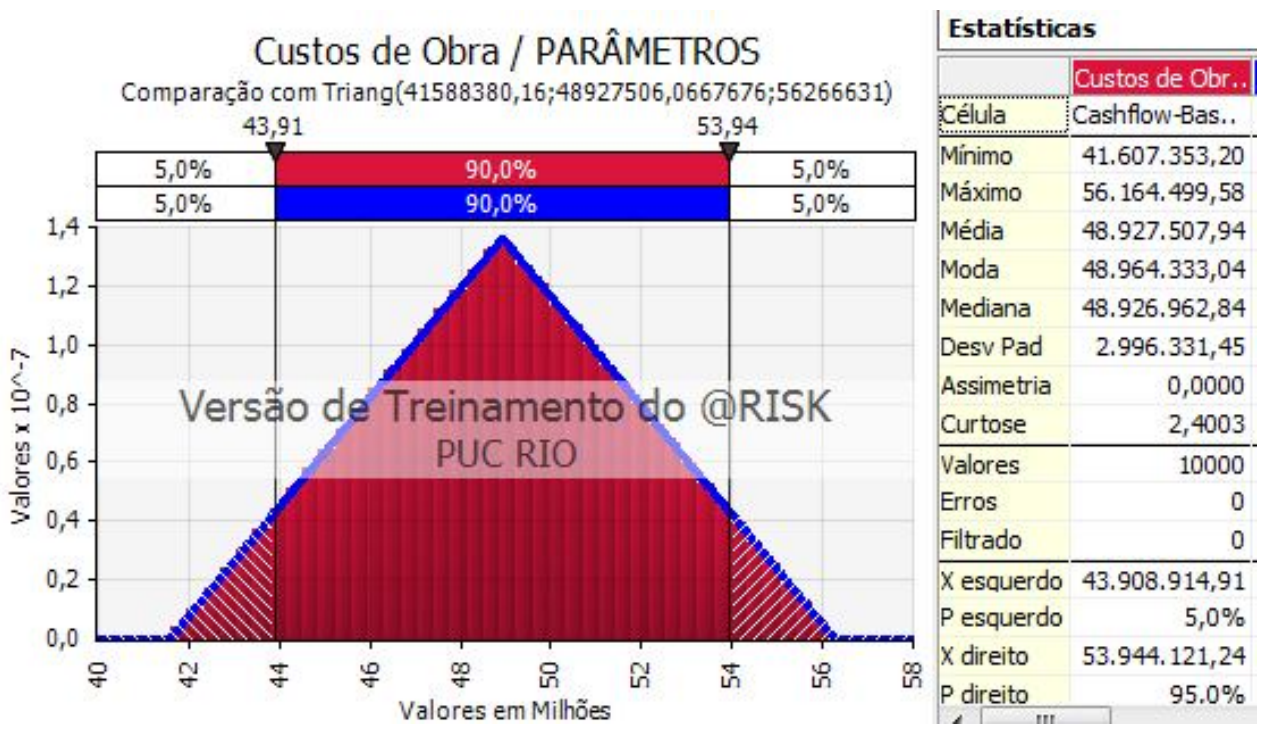

Figura 11: Distribuição Triangular para o Custo de Construção no

\section{Cenário Base}

A curva de obra apresenta um desvio padrão de $\mathrm{R} \$ 2.9 \mathrm{MM}$. O numero máximo atingido é $\mathrm{R} \$ 56.1 \mathrm{MM}$ e o mínimo $\mathrm{R} \$ 41.6 \mathrm{MM}$. Existem $90 \%$ chances do custo 
estar entre $\mathrm{R} \$ 43.9 \mathrm{MM}$ e $\mathrm{R} \$$ 53.9. Portanto, por menor a probabilidade, pode existir a chance de haver tanto um estouro quanto uma redução de custo de obra.

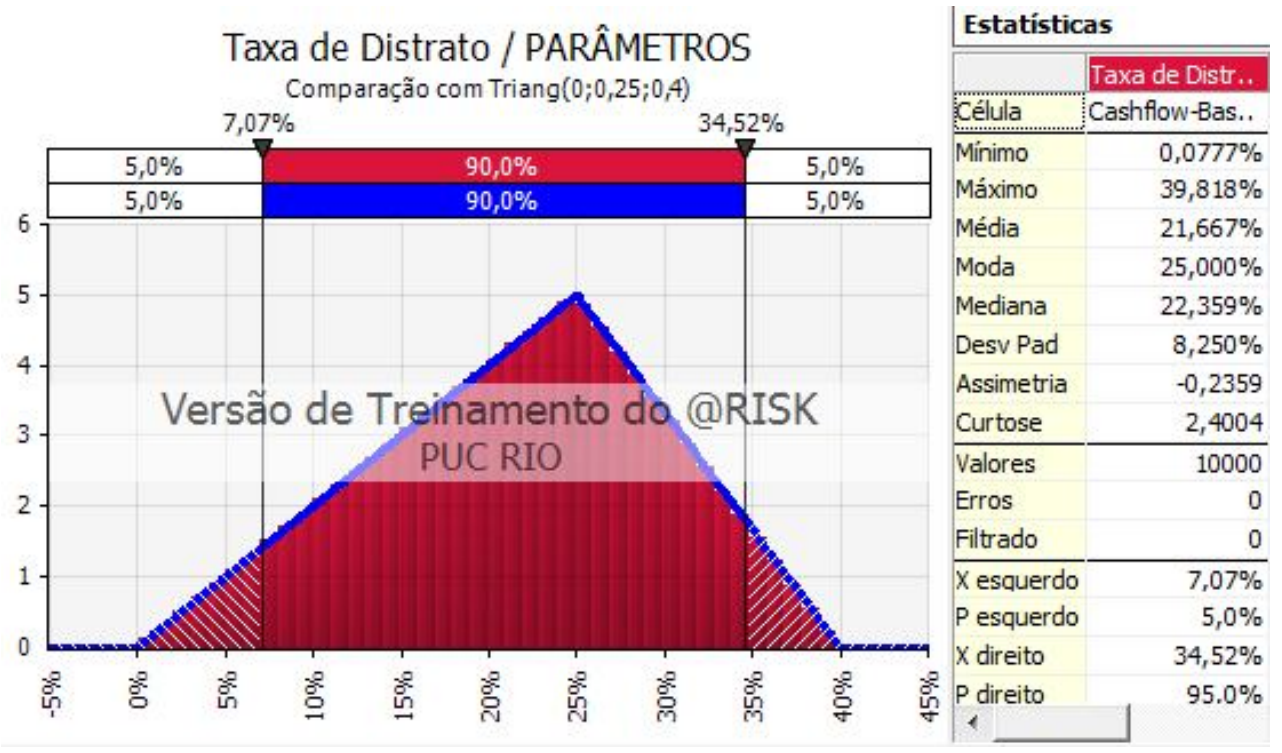

Figura 12: Distribuição Triangular para a Taxa de Distrato no Cenário Base

Considerando a distribuição triangular do percentual de unidades distratadas, verifica-se que em $90 \%$ dos casos a taxa de distrato ficará entre $7 \%$ a $34 \%$. 


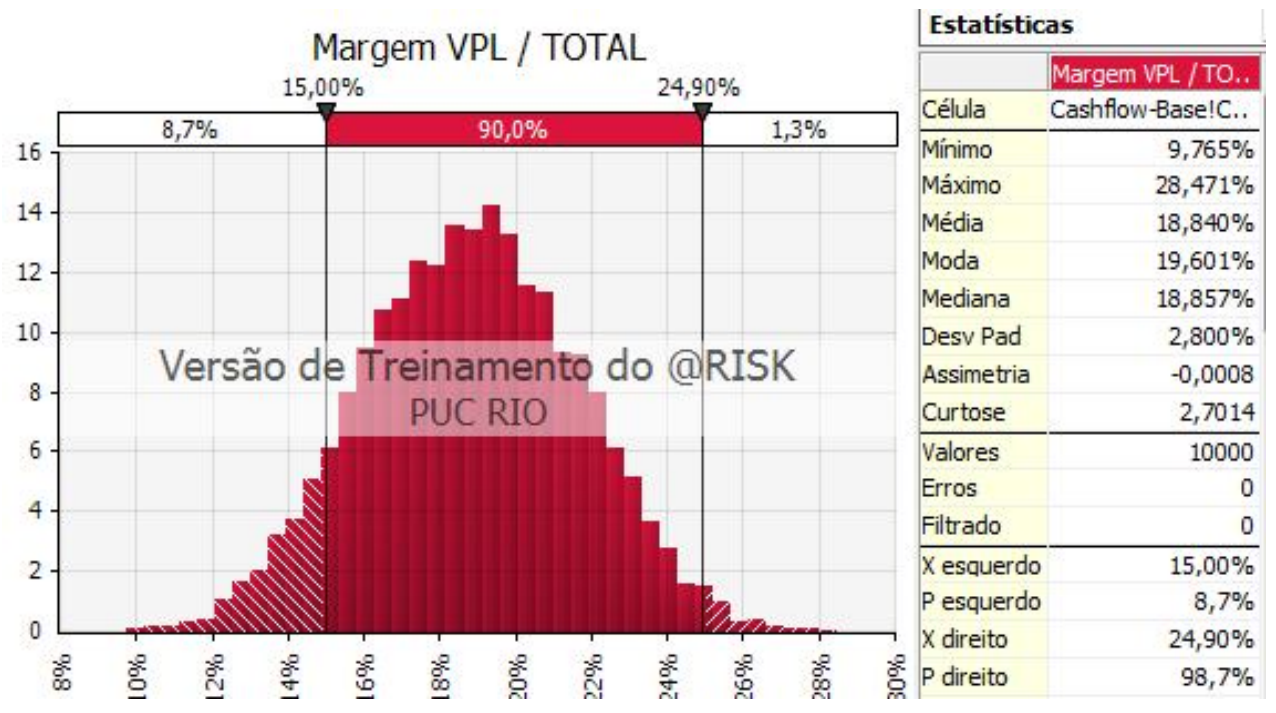

Figura 13: Simulação de Risco da Margem VPL no Cenário Base

Ao atribuir probabilidades nas variáveis dependentes- taxa de desconto, custo de construção e taxa de desistência, os distratos, verifica-se que existem $8,7 \%$ de chances do projeto atingir uma margem VPL abaixo do gatilho de $15 \%$. Do mesmo modo, em $90 \%$ dos casos, a margem ficará entre $15 \%$ a $24,9 \%$. 


\section{5 \\ Conclusão}

Os projetos imobiliários necessitam de grande aporte de capital antes mesmo do lançamento ao mercado. Além disso, em função do seu longo ciclo, tal setor é diretamente afetado pela situação macroeconômica do país.

Esse trabalho pretendeu evidenciar a necessidade da análise de risco no estudo de viabilidade de um projeto imobiliário. Para atingir os objetivos pretendidos, realizou-se uma análise de sensibilidade de quatro cenários: base, otimista, pessimista e stress. Foram selecionados os cenários otimista e pessimista, pois estes eram, respectivamente, a expectativa e a realidade das incorporadoras. Ao utilizar o Value At Risk, foi constatado que existem probabilidades de perda e de ganho e estas devem ser incorporadas no estudo de viabilidade.

Usualmente, veem-se na prática muitos analistas já incorporando essas opções intuitivamente na avaliação de investimentos. É importante, todavia estabelecer uma cultura empresarial de forma a quantificar essas opções com base em critérios objetivos e seguros, detectando as incertezas mais relevantes e sabendo utilizá-las a seu favor,

Ao adotar a análise de risco em seus estudos de viabilidade de projeto imobiliário, os acionistas podem definir se devem optar pela redução do preço do imóvel a fim de acelerar a curva de vendas. Dependendo do cenário base, é possível optar pela postergação do investimento ou definir pelo lançamento faseado até que se encontre melhores condições de mercado. A análise de risco permite também avaliar a alavancagem do projeto.

Neste trabalho, não foi analisado empreendimentos comerciais. Para trabalhos futuros, seria interessante analisar o risco deste tipo de empreendimento visto que o percentual de financiamento bancário é menor, as taxas oferecidas pelos bancos são maiores e a incidência de desistência e superior quando comparado aos empreendimentos comerciais.

Pode-se também, aprofundar os impactos dos distratos no fluxo de caixa na viabilidade de projetos imobiliários. Este estudo considerou que os clientes aceitariam uma retenção de $50 \%$, contudo, a jurisprudência garante a devolução 
de $80 \%$ do valor pago corrigido monetariamente. Estes valores ocasionarão um impacto maior no fluxo de caixa do projeto.

Outra recomendação para os próximos estudos que sejam realizados métodos de gerenciamento dos riscos imobiliários através de modelos de análise apresentados neste trabalho. 


\section{6 \\ Referências bibliográficas}

ABECIP. Financiamento Imobiliário. Disponível em: < https://www.abecip.org.br/credito-imobiliario/indicadores/financiamento>. Acesso em: 25 de novembro, 2015,

BAWA, V. S. Safety-Firt, Stocashastic Dominance, and Optimal Portifolio Choice. Journal of Finance and Quantitative Analysis. p.13:2, 255-71. 1978.

Banco Central do Brasil. Relatório de Inflação. Disponível em: < https://www.bcb.gov.br/?RI >. Acesso em: 25 de novembro, 2015.

BREALEY, V. A.; MYRES, S. C. Princípios de Finanças Empresariais, Terceira Edição, Portugal: Editora McGraw Hill, 1992.

Bureau of Labor Statistics, U.S. Department of Labor. Consumer Price Index. Disponível em: <http://data.bls.gov/pdq/SurveyOutputServlet>. Acesso em: 25 de setembro, 2015.

CASAROTTO, F.; KOPITTKE, H. Análise de Investimentos. 9o Edição São Paulo: Atlas, 2000.

COPELAND, T.; WESTON, F.; SHASTRI, K. Financial Theory and corporate policy. 4th. Ed. Pearson Addison Wesley. 2005.

COSTA, S.; ATTIE, V. Análise de Projetos, Rio de Janeiro: Editora da Fundação Getúlio Vargas, 1987.

Damodaran Online. Annual Returns on Stock, T.Bonds and T.Bills: 1928 Current. Disponível em: <pages.stern.nyu.edu/ adamodar/>. Acesso em: 25 de novembro, 2015.

EBRAHIM, M. S.; HUSSAIN, S. Financial development and asset valuation: The special case of real estate. Journal of Banking \& Finance, v. 34, n. 1, p. 150162, 2010.

FEW, J.; JUD, G. D. The Vacancy Rate and Rent Levels in the Commercial Office Market, Journal of Real Estate Research, 3:1, 1-8, 1988.

FORTUNATO, G.; BRANDÃO, L. E.; ROZEMBAUM, S. R.; Valor da Opção de Abandono em Lançamentos Imobiliários Residenciais. RAC Eletrônica (Online), v. 2, p. 531-545, 2008.

GREBLER, L.; BURNS, L. S. Construction Cycles um the United States Since World War II, AREUA Journal, 16:1, 77-83,1988.

IPEA Data. EMBI+ Risco-Brasil. Disponível em: 
$<w w w . i p e a d a t a . g o v . b r / E x i b e S e r i e . a s p x$ ?serid $=40940 \&$ module $=M>$. Acesso em: 25 de novembro, 2015.

JORION, P. Value At Risk: The New Benchmark for Controlling Derivatives Risk. New York:McGraw-Hill,1997.

KOETTER, M.; POGHOSYAN, T. Real estate prices and bank stability. Journal of Banking \& Finance, v. 34, n. 6, p. 1129-1138, 2010.

KURUC, A.; LEE, B. How to Trim your Hedge. Risk, 11, 46-9,1998.

LUEHRMAN, T. A. Using APV: a better tool for valuing operation. Harvard Business Review, v. 65, n. 3, p. 145-154, 1997.

NARULA, S. C.; WELLINGTON, J. F.; LEWIS, S. A. Valuating residential real estate using parametric programming. European Journal of Operational Research, v. 217, n. 1, p. 120-128, 2012.

ROULAC, S. E. Valuation Decisions in a Turbulent Economy: Challenge to Tradition, Opportunity for Distinction, Appraisal Journal, 50:4, 564-80, 1982.

Secovi Rio. Pesquisas e Indicadores. Disponível em: <http://www.secovirio.com.br/Pesquisas-e-Indicadores-163>. Acesso em 25 de novembro de 2015.

WHEATON, W. C. The Behavior of the National Office Market, AREUA Journal, 15:4, 281-99. 1987.

WITTEN, R. G. Riding the Real Estate Cycle, Real Estate Today, $42-48$ August 1987. 